Chapter 2

\title{
Fuel Production Using Concentrated Solar Energy
}

\author{
Onur Taylan and Halil Berberoglu \\ Additional information is available at the end of the chapter \\ http://dx.doi.org/10.5772/54057
}

\section{Introduction}

Limited reserves of fossil fuels and their negative environmental effects impose significant problems in our energy security and sustainability. Consequently, researchers are looking for renewable energy sources, for instance solar energy, to meet the energy demands of a growing world population. However, terrestrial solar energy is a dilute resource per footprint area and is intermittent showing substantial variability depending on the season, time of the day, and location.

One strategy to overcome these drawbacks of solar energy is to concentrate and use it for cleaning and upgrading dirty fuels such as coal and other hydrocarbons or converting renewable feedstocks such as biomass into carbon-neutral solar fuels. In this way, the intermittent and dilute solar energy can be concentrated and stored as a chemical fuel which can be easily integrated to our existing energy infrastructure. These advantages of solar fuels produced with concentrated solar radiation make them an attractive solution in our quest for renewable and clean fuels. Figure 1 shows the energy potential and carbon emissions by most commonly used fuels along with solar hydrogen.

Most common and available methods for solar fuel production are thermolysis, cracking, reforming, gasification and through thermochemical cycles. All these methods require high temperatures to produce solar fuel. Therefore, in these methods, there are some qualities of the feedstock or the reactor that need to be satisfied to attain high temperatures and efficient solar fuel production. For instance, the physical size and porosity of the feedstock play an important role. As the surface area-to-volume ratio of the feedstock increases, more reaction sites will be available for the reaction to occur, which increases the process efficiency. The feedstock should also have a narrow bad gap to lower the energy requirement for chemical process. Additionally, the material on the reactor walls should have high optical absorption to increase the temperature of the reactor and withstand high temperatures, and the win- 
dow material should have high transmissivity to let the solar energy in to the reactor. More detailed property requirements are given by Nowotny et al. [1].

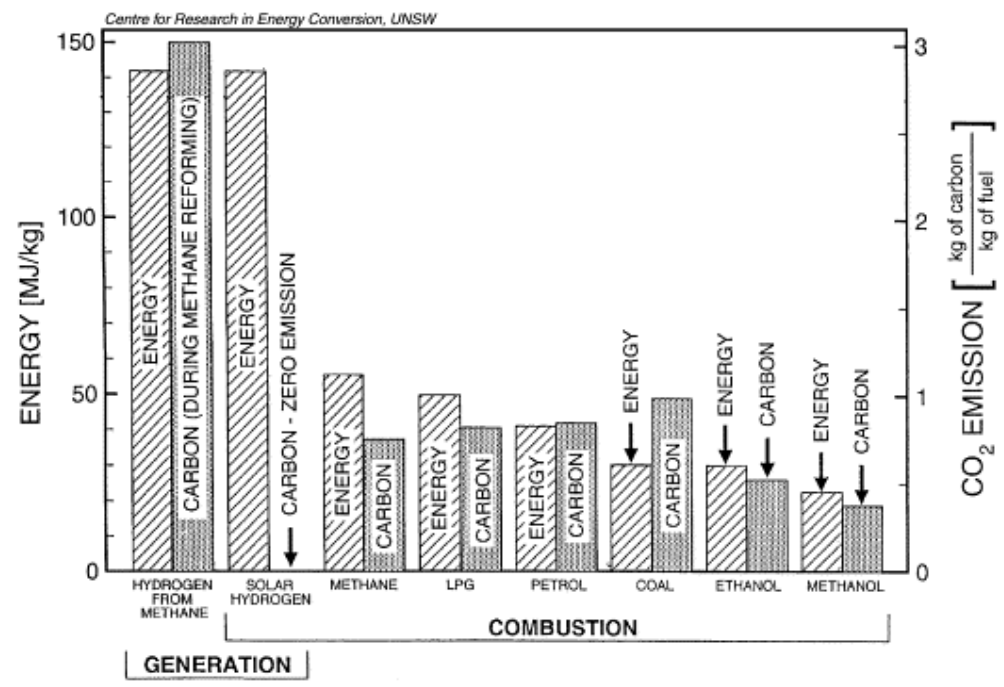

Figure 1. Comparison of different fuels in terms of their energy produced and $\mathrm{CO}_{2}$ emission [1].

This review chapter consists of four sections. Following the introduction, the second section "Concentrated Solar Fuel Production Methods" reviews the different routes of producing solar fuels according to the feedstock material used in the processes. These include (i) thermolysis of water, (ii) thermochemical cycles, (iii) cracking of gaseous hydrocarbons, and (iv) gasification and reforming of coal and biomass. These methods are compared with each other based on their temperature, pressure, thermodynamic efficiencies, and by-products. The third section "Concentrated Solar Reactors" provides a comprehensive review of different concentrated solar reactor designs reported in the literature. This section first reviews the current solar concentration methods and describes in detail the effects of concentrating factors on the heat flux and temperatures that can be achieved. Then, the section describes the design and basic principles of operation of different solar reactors, their applicability for the different methods described in the preceding section, and their temperature and pressure capabilities. Moreover, the section summarizes the reported solar to fuel conversion efficiencies of each design. Finally, the chapter ends with the conclusions and outlook of fuel production with concentrated solar energy outlining the challenges, new research directions and novel applications. 


\section{Concentrated solar fuel production methods}

This section describes different methods of producing solar fuels according to the feedstock material used in the respective processes.

\subsection{Thermolysis of water}

The term "thermolysis of water" refers to the thermal decomposition of water molecules into hydrogen and oxygen gases. Historically, due to high availability and simple molecular form of water, researches on solar fuel production started with direct hydrogen production by thermolysis of water using solar energy as,

$$
\begin{aligned}
& \mathrm{H}_{2} \mathrm{O} \rightarrow \mathrm{H}_{2}+1 / 2 \mathrm{O}_{2} \\
& \Delta \mathrm{H}_{300 \mathrm{~K}}=286 \mathrm{~kJ} / \mathrm{mol}
\end{aligned}
$$

The reaction given in Equation (1) is an endothermic process, i.e., it requires energy to break the bonds. However, breaking all the bonds in water molecules requires temperatures as high as $2500 \mathrm{~K}$ [2]. At lower temperatures, partial decomposition occurs. Although it is possible to reach $2500 \mathrm{~K}$ with concentrated solar energy, the reactor where this process takes place shows material issues related to high temperatures. Additionally, after the dissociation of water molecules, hydrogen and oxygen gases require separation at high temperatures in order to prevent back-bonding, i.e., reproduction of water molecules with an exothermic process. Some solutions include cooling the reactor down by injecting a gas or expanding these gases through nozzle at the end of the reactor $[2,3]$. Other solutions include using double or tubular membranes or using multi-stage steam ejectors to lower the exit pressure [4]. However, these solutions further reduce the efficiency of the process, and thus no commercial plant using this technology exists.

\subsection{Thermochemical cycles}

Some metal oxides are reduced using solar energy since metals provide good storage and transport of energy, such as solar energy. Such metal oxides include, but not limited to $\mathrm{ZnO}$, $\mathrm{MgO}, \mathrm{SnO}_{2}, \mathrm{CaO}, \mathrm{Al}_{2} \mathrm{O}_{3}$ and $\mathrm{Ce}_{2} \mathrm{O}_{3}$. The reduction step of these metal oxides is generally followed by an oxidation step at lower temperatures than reduction step in order to produces solar fuel, mainly hydrogen. The reduced metal oxides generally react with $\mathrm{CO}_{2}$ or steam. If steam is used in oxidation that step is called hydrolysis. The thermochemical cycles of different metal oxides are generally compared based on their temperature requirements for the reduction step, the reaction or dissociation rates and reaction kinetics.

$\mathrm{ZnO}$ is one of the most popular oxides mainly due to its abundance and relatively low temperature requirement for complete dissociation when compared to other metal oxides. Additionally, since $\mathrm{ZnO}$ is a simple metal oxide, it does not undergo multiple reactions before its full dissociation. The dissociation of $\mathrm{ZnO}$ occurs as according to, 


$$
\begin{aligned}
& \mathrm{ZnO} \rightarrow \mathrm{Zn}+1 / 2 \mathrm{O}_{2} \\
& \Delta \mathrm{H}_{2000 \mathrm{~K}}=546 \mathrm{~kJ} / \mathrm{mol}
\end{aligned}
$$

The complete dissociation of $\mathrm{ZnO}$ to $\mathrm{Zn}$ requires temperatures higher than about $2300 \mathrm{~K}$ whereas, for instance, the dissociation of $\mathrm{MgO}$ as another simple metal oxide requires about $3700 \mathrm{~K}$ at atmospheric pressures [3, 5]. As in water thermolysis, partial dissociations can occur at lower temperatures. Although hydrolysis of zinc is exothermic as given by Equation (3), only $24 \%$ of $\mathrm{Zn}$ could be oxidized to produce $\mathrm{H}_{2}$ at a reactor temperature of $800 \mathrm{~K}$ and an atmospheric pressure [6].

$$
\begin{aligned}
& \mathrm{Zn}+\mathrm{H}_{2} \mathrm{O} \rightarrow \mathrm{ZnO}+\mathrm{H}_{2} \\
& \Delta \mathrm{H}_{300 \mathrm{~K}}=-62 \mathrm{~kJ} / \mathrm{mol}
\end{aligned}
$$

Figure 2 shows the overall process of hydrogen production from zinc-oxide.

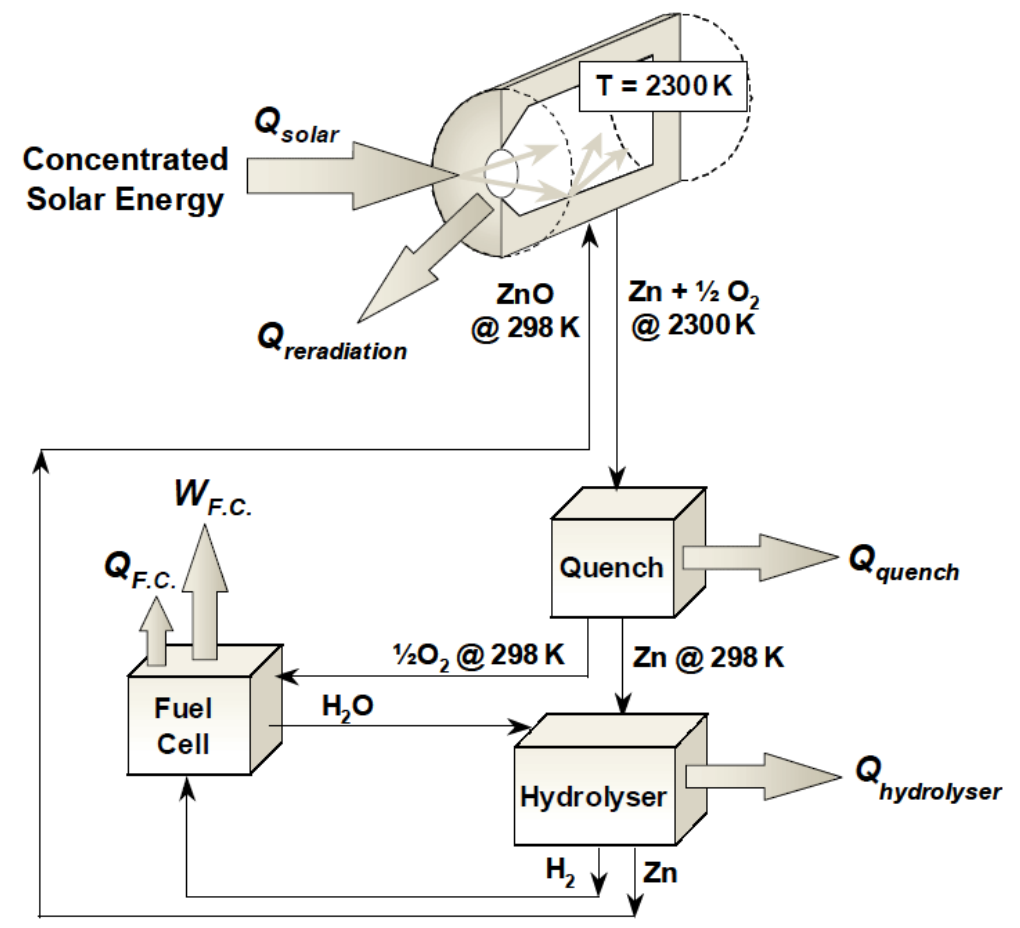

Figure 2. Flowchart for thermochemical hydrogen production from zinc-oxide using concentrated solar energy [5]. 
As an alternative to $\mathrm{ZnO}$ reduction, Abanades et al. [7] proposed $\mathrm{SnO}_{2}$ reduction using solar energy. Once the $\mathrm{SnO}_{2}$ is reduced to $\mathrm{SnO}$ in gaseous form using solar energy at temperatures nearly $1600^{\circ} \mathrm{C}$, hydrolysis of $\mathrm{SnO}$ with steam at about $550^{\circ} \mathrm{C}$ and ambient pressure takes place in another step to form hydrogen gas as,

$$
\begin{gathered}
\mathrm{SnO}_{2(\mathrm{~s})} \rightarrow \mathrm{SnO}_{(\mathrm{g})}+1 / 2 \mathrm{O}_{2} \\
\Delta \mathrm{H}_{1873 \mathrm{~K}}=557 \mathrm{~kJ} / \mathrm{mol} \\
\mathrm{SnO}_{(\mathrm{s})}+\mathrm{H}_{2} \mathrm{O}_{(\mathrm{g})} \rightarrow \mathrm{SnO}_{2(\mathrm{~s})}+\mathrm{H}_{2} \\
\Delta \mathrm{H}_{773 \mathrm{~K}}=-49 \mathrm{~kJ} / \mathrm{mol}
\end{gathered}
$$

The advantages of $\mathrm{SnO}_{2} / \mathrm{SnO}$ reduction when compared to $\mathrm{ZnO} / \mathrm{Zn}$ reduction are that (i) the $\mathrm{SnO}_{2}$-to-SnO conversion can be increased in Equation (4) by decreasing the pressure of the solar reactor which increases the overall conversion efficiency [7] (ii) SnO has higher melting and boiling points when compared to those of $\mathrm{Zn}$, so that quenching rate of $\mathrm{SnO}$ is not as important as of $\mathrm{Zn}$ [7] (iii) in $\mathrm{ZnO} / \mathrm{Zn}$ dissociation, $\mathrm{Zn}$ needs to be quenched rapidly below its condensation temperature to prevent recombination, while this is not the case with $\mathrm{SnO}_{2} / \mathrm{SnO}$ system.

There are some other metals that can be reduced with faster reaction kinetics such as $\mathrm{Ce}_{2} \mathrm{O}_{3}$. However, the reduction of $\mathrm{Ce}_{2} \mathrm{O}_{3}$ to $\mathrm{CeO}_{2}$ starts at temperatures higher than $2300 \mathrm{~K}[8,9]$. Full dissociation requires higher temperatures. This requirement of high temperatures creates some material limitations on the material of the reactor and increases the cost of the reactor significantly. Although there are some lab-scale prototypes of $\mathrm{Ce}_{2} \mathrm{O}_{3} / \mathrm{CeO}_{2}$ solar reactor, it is not preferred due to these limitations and high cost.

Another research was also started with producing hydrogen gas from hydrogen sulfide, $\mathrm{H}_{2} \mathrm{~S}$, as,

$$
\begin{aligned}
& \mathrm{H}_{2} \mathrm{~S} \rightarrow \mathrm{H}_{2}+1 / 2 \mathrm{~S}_{2} \\
& \Delta \mathrm{H}_{300 \mathrm{~K}}=91.6 \mathrm{~kJ} / \mathrm{mol}
\end{aligned}
$$

Hydrogen sulfide is a toxic by-product gas of sulfur removing process from natural gas, petroleum and coal. Thermal decomposition of hydrogen sulfide requires about $1800 \mathrm{~K}$ [10]. It is advantageous over the other metal oxide reduction processes discussed above since this thermochemical process is only a one-step process that does not require additional oxidation step to produce hydrogen. Additionally, the temperature requirement for dissociation is lower than that for the direct water thermolysis. However, the product gases need to be cooled down after the dissociation as in the water thermolysis or other metal oxide reduction processes [11]. Some studies showed that the temperature of reduction could be reduced to about $1500 \mathrm{~K}$, and they showed that the reproduction of hydrogen sulfide is unimportant below $1500 \mathrm{~K}[3,12,13]$. 
In general, the solar chemical process is a clean way to produce hydrogen without any carbon prints. Therefore, the hydrogen as a product of the solar chemical process can be used in fuel cells directly as it is pure. The solar chemical reduction step of the process produce nanoparticles with high surface area to volume ratio, e.g., $\mathrm{Zn}, \mathrm{SnO}$ which also create additional reaction centers for the hydrolysis to occur [7]. Therefore, the oxidation or hydrolysis occurs fast due to high mass transport of gases in the solid phase [7]. As in the other dissociation processes, the products of the dissociation also need to be cooled in order to prevent re-oxidation. Sandia National Laboratories of US released a comprehensive report on the thermochemical cycle selection with initial selection for further research [14], and Table 1 summarizes the studied thermochemical cycles [15].

\subsection{Cracking of gaseous hydrocarbons}

The term "solar thermal cracking" or "solar cracking" is used for thermal decarbonization of natural gas or other hydrocarbons. As a result of cracking, hydrogen, carbon and other possible products are formed without $\mathrm{CO}_{2}$ emissions. Therefore, this process is another method for clean fuel production. Cracking requires high temperatures of about $1500 \mathrm{~K}$ [16] that can be reached using concentrating solar collectors. For example, Maag et al. [17] tested a concentrated solar collector with a concentrating factor of 1720, and obtained a maximum temperature of $1600 \mathrm{~K}$ within the solar cavity reactor. In general, the advantages of solar cracking are the increase in value of feedstock using solar energy, pure and uncontaminated products and no $\mathrm{CO}_{2}$ emission [16].

As being the simplest hydrocarbon and the main constituent of natural gas as given in Table 2 , methane has been mainly considered for solar cracking. Chemical reaction of evolution of carbon black and methane is given in equation (7) $[18,19]$. The kinetic mechanism of methane cracking at $1500 \mathrm{~K}$ and atmospheric pressure was proposed as [20, 21],

$$
2 \mathrm{CH}_{4} \rightarrow \mathrm{C}_{2} \mathrm{H}_{6}+\mathrm{H}_{2} \rightarrow \mathrm{C}_{2} \mathrm{H}_{4}+2 \mathrm{H}_{2} \rightarrow \mathrm{C}_{2} \mathrm{H}_{2}+3 \mathrm{H}_{2} \rightarrow 2 \mathrm{C}_{(\text {solid })}+4 \mathrm{H}_{2}
$$

Another important aspect of producing hydrogen and carbon black (solid carbon) is their market values. Hydrogen and carbon black have a market value of about $\$ 135$ billion per year and between $\$ 7$ and $\$ 11$ billion per year depending on the grade of the carbon black in the world, respectively [22].

Under an EU project named SOLHYCARB, a 50- $\mathrm{kW}_{\text {th }}$ indirectly heated, cavity type solar reactor was developed for methane cracking [8]. Its 10- $\mathrm{kW}_{\text {th }}$ prototype was built and tested using natural gas, and $97 \%$ conversion was obtained with a maximum temperature above 2000 $\mathrm{K}$ under concentrated solar irradiation of $4 \mathrm{MW} / \mathrm{m}^{2}$ [23]. The difficulties that prevent this technology to become commercial are mainly the cost of the reactor and the complicated flow pattern inside the reactors. For example, in order to prevent particle accumulation on the window, some inert gas is introduced to the reactor with high flow rates and pressures, or indirectly heated solar reactors are used which decreases the solar-to-fuel conversion efficiency and further increase the cost. 


\begin{tabular}{|c|c|}
\hline Cycle & Reaction Steps \\
\hline \multicolumn{2}{|l|}{ High Temperature Cycles } \\
\hline $\mathrm{Zn} / \mathrm{ZnO}$ & $\begin{array}{l}\mathrm{Fe}_{3} \mathrm{O}_{4} \stackrel{2000-2300^{\circ} \mathrm{C}}{\rightarrow} 3 \mathrm{FeO}+1 / 2 \mathrm{O}_{2} \\
3 \mathrm{FeO}+\mathrm{H}_{2} \mathrm{O} \stackrel{400^{\circ} \mathrm{C}}{\rightarrow} \mathrm{Fe}_{3} \mathrm{O}_{4}+\mathrm{H}_{2}\end{array}$ \\
\hline $\mathrm{FeO} / \mathrm{Fe}_{3} \mathrm{O}_{4}$ & $\begin{array}{l}\mathrm{CdO} \stackrel{1450-1500^{\circ} \mathrm{C}}{\rightarrow} \mathrm{Cd}+1 / 2 \mathrm{O}_{2} \\
\mathrm{Cd}+\mathrm{H}_{2} \mathrm{O}+\mathrm{CO}_{2} \rightarrow \mathrm{CdCO}_{3}+\mathrm{H}_{2} \\
\mathrm{CdCO}_{3} \stackrel{500^{\circ} \mathrm{C}}{\rightarrow} \mathrm{CO}_{2}+\mathrm{CdO}\end{array}$ \\
\hline Cadmium carbonate & $\begin{array}{l}\mathrm{CdO} \stackrel{1450-1500^{\circ} \mathrm{C}}{\rightarrow} \mathrm{Cd}+1 / 2 \mathrm{O}_{2} \\
\mathrm{Cd}+2 \mathrm{H}_{2} \mathrm{O} \stackrel{25^{\circ} \mathrm{C} \text {,electrochemical }}{\rightarrow} \mathrm{Cd}(\mathrm{OH})_{2}+\mathrm{H}_{2} \\
\mathrm{Cd}(\mathrm{OH})_{2}{ }_{3}^{375^{\circ} \mathrm{C}} \mathrm{CdO}+\mathrm{H}_{2} \mathrm{O}\end{array}$ \\
\hline Hybrid cadmium & $\begin{array}{l}\mathrm{Mn}_{2} \mathrm{O}_{3} \stackrel{1400-1600^{\circ} \mathrm{C}}{\rightarrow} 2 \mathrm{MnO}+1 / 2 \mathrm{O}_{2} \\
2 \mathrm{MnO}+2 \mathrm{NaOH} \stackrel{627^{\circ} \mathrm{C}}{\rightarrow} 2 \mathrm{NaMnO}_{2}+\mathrm{H}_{2} \\
2 \mathrm{NaMnO}_{2}+\mathrm{H}_{2} \mathrm{O} \stackrel{25^{\circ} \mathrm{C}}{\rightarrow} \mathrm{Mn}_{2} \mathrm{O}_{3}+2 \mathrm{NaOH}\end{array}$ \\
\hline Sodium manganese & $\begin{array}{l}\mathrm{Fe}_{3-x} \mathrm{M}_{x} \mathrm{O}_{4} \stackrel{1200-1400^{\circ} \mathrm{C}}{\rightarrow} \mathrm{Fe}_{3-x} \mathrm{M}_{x} \mathrm{O}_{4-y}+y / 2 \mathrm{O}_{2} \\
\mathrm{Fe}_{3-x} \mathrm{M}_{x} \mathrm{O}_{4-y}+y \mathrm{H}_{2} \mathrm{O} \stackrel{1000-1200^{\circ} \mathrm{C}}{\rightarrow} \mathrm{Fe}_{3-x} \mathrm{M}_{x} \mathrm{O}_{4}+y \mathrm{H}_{2}\end{array}$ \\
\hline$M$-Ferrite $(M=\mathrm{Co}, \mathrm{Ni}, \mathrm{Zn})$ & $\begin{array}{l}\mathrm{H}_{2} \mathrm{SO}_{4}{ }^{850^{\circ} \mathrm{C}} \mathrm{SO}_{2}+\mathrm{H}_{2} \mathrm{O}+1 / 2 \mathrm{O}_{2} \\
\mathrm{I}_{2}+\mathrm{SO}_{2}+2 \mathrm{H}_{2} \mathrm{O} \rightarrow 2 \mathrm{100}{ }^{\circ} \mathrm{C} \\
\quad 300^{\circ} \mathrm{C}+\mathrm{H}_{2} \mathrm{SO}_{4} \\
2 \mathrm{HI} \rightarrow \mathrm{I}_{2}+\mathrm{H}_{2}\end{array}$ \\
\hline Low Temperature Cycles & \\
\hline Sulfur-lodine & $\begin{array}{l}\mathrm{H}_{2} \mathrm{SO}_{4}{ }^{850^{\circ} \mathrm{C}} \mathrm{SO}_{2}+\mathrm{H}_{2} \mathrm{O}+1 / 2 \mathrm{O}_{2} \\
\mathrm{SO}_{2}+2 \mathrm{H}_{2} \mathrm{O} \stackrel{77^{\circ} \mathrm{C} \text { electrochemical }}{\rightarrow} \mathrm{H}_{2} \mathrm{SO}_{4}+\mathrm{H}_{2}\end{array}$ \\
\hline Hybrid sulfur & $\begin{array}{l}\mathrm{Cu}_{2} \mathrm{OCl}_{2} \rightarrow 20^{\circ} \mathrm{C} \\
\mathrm{CCu}+2 \mathrm{CCl}+1 / 2 \mathrm{O}_{2} \\
\stackrel{425^{\circ} \mathrm{C}}{\rightarrow} \mathrm{H}_{2}+2 \mathrm{CuCl} \\
4 \mathrm{CuCl} \stackrel{25^{\circ} \mathrm{C} \text {,electrochemical }}{\rightarrow} 2 \mathrm{Cu}+2 \mathrm{CuCl}_{2} \\
2 \mathrm{CuCl}_{2}+\mathrm{H}_{2} \mathrm{O}^{325^{\circ} \mathrm{C}} \rightarrow \mathrm{Cu}_{2} \mathrm{OCl}_{2}+2 \mathrm{HCl}\end{array}$ \\
\hline Hybrid copper chloride & $2 \mathrm{CH}_{4} \rightarrow \mathrm{C}_{2} \mathrm{H}_{6}+\mathrm{H}_{2} \rightarrow \mathrm{C}_{2} \mathrm{H}_{4}+2 \mathrm{H}_{2} \rightarrow \mathrm{C}_{2} \mathrm{H}_{2}+3 \mathrm{H}_{2} \rightarrow 2 \mathrm{C}_{\text {(solid) }}+4 \mathrm{H}_{2}$ \\
\hline
\end{tabular}

Table 1. Summary of Thermochemical Cycles [15]. 


\begin{tabular}{ccccccc}
\hline & \multicolumn{5}{c}{ Volume Fractions (\%) } \\
\hline Methane & $\mathrm{CH}_{4}$ & $\mathrm{C}_{2} \mathrm{H}_{6}$ & $\mathrm{C}_{3} \mathrm{H}_{8}$ & $\mathrm{C}_{4} \mathrm{H}_{10}$ & $\mathrm{CO}_{2}$ & - \\
\hline Modified Algeria Gas & 100 & - & - & - & $\mathbf{N}_{2}$ \\
\hline Modified Groningen Gas & 91.2 & 6.5 & 2.1 & 0.2 & - & - \\
\hline North Sea Gas & 83.5 & 4.7 & 0.7 & 0.2 & - & 10.8 \\
\hline
\end{tabular}

Table 2. Compositions of Natural Gas from Different Sources [20].

\subsection{Gasification and reforming of coal and biomass}

Gasification is a chemical process that converts carbonaceous feedstock into gaseous fuels under a controlled amount of oxygen and/or steam [24]. Main difference between gasification and combustion is that products in gasification have useful heating value. In gasification, pressure inside the gasifier is generally in the range from 20 to 40 bar, whereas methanol or ammonia synthesis requires 50 to 200 bar [25]. In addition, temperatures inside the gasifier is generally in the range from 1400 to $1700^{\circ} \mathrm{C}$ [25].

Pyrolysis is a thermochemical process that occurs before gasification, and it decomposes the complex hydrocarbons into smaller and less complex molecules in the absence of oxidizers. In pyrolysis, the yield of solar char can be maximized by slowing the heating rate, lowering the temperature or allowing a longer residence time [26]. On the contrary, a higher heating rate, a higher temperature, and a shorter residence time maximize the gas yield. Additionally, liquid yield at an intermediate temperature can be maximized by increasing the heating rate or minimizing the residence time. Tar is an undesired by-product of gasification and pyrolysis. It can cause condensation and consequent plugging, formation of aerosols and polymerization into more complex structures [26].

Gasification is an endothermic process and requires energy to occur. In case of conventional gasification, this energy is supplied from the partial combustion or gasification of feedstock which emits $\mathrm{CO}_{2}$ to the atmosphere. Use of concentrated solar energy eliminates or reduces the $\mathrm{CO}_{2}$ emission and utilizes the clean high-temperature gasification process. Additionally, fuel value of the feedstock is increased with solar gasification. For example, fuel value of coal can be increased by about $45 \%$ using solar coal gasification [27], and $\mathrm{CO}_{2}$ emission can be reduced by about $30 \%$ when compared to conventional coal gasification [28].

Solar gasification of coal and other carbonecous products is the process of converting these feedstock materials into some synthesis gas (syngas) which includes $\mathrm{H}_{2}, \mathrm{CO}, \mathrm{CO}_{2}$ and water vapor using solar energy [29]. The gasification products can be further processed. For example, syngas can be processed to form methanol or ammonia or used in cement production, and lean gas can be combusted for heating or used in power stations to generate electricity 
$[16,30]$. Solar gasification can be performed using $\mathrm{CO}_{2}$ or steam. In general, steam gasification of coal can be written as,

$$
\mathrm{Coal}+\mathrm{aH}_{2} \mathrm{O} \rightarrow \mathrm{bH}_{2}+\mathrm{cCO}+\mathrm{dCO}_{2}
$$

This process is endothermic and requires temperatures above $1000^{\circ} \mathrm{C}$. Solar gasification of petcoke, coal and other carbonecous feedstock started with directly irradiated solar reactors [31]. These designs have high reaction rates and kinetic and high fuel-to-product conversion. However, these reactors have problems with their aperture cover. As a cover, quartz window is commonly used to allow the concentrated solar power into the reactor. In directly irradiated reactors, quartz window has to withstand the high pressures inside the reactor and should not be covered with particles as the gasification occurs. As in the solar cracking, additional flows of inert gases are introduced into the reactor to prevent particle accumulation on the quartz window, but these additional flows introduce additional complexity and cost to the reactor [30]. In EU project SOLSYN [31], a 5-kW reactor prototype was built for solar coal gasification. The temperatures in this reactor could go up to $1700^{\circ} \mathrm{C}$ with the solar concentrating ratio of nearly 3000, but the general operation temperature was kept at $1220^{\circ} \mathrm{C}$. The peak conversion efficiency was found to be $29 \%$ [31].

Similar to coal and other carbonecous feedstock, biomass can also be gasified in solar reactors. Conventionally, gasification of biomass has been done using the exhaust gas of combustion of fossil fuels or biomass itself. Biomass includes demol wood, wood chips, sewage sludge, almond shells, straw, etc. If the biomass is used, nearly $30 \%$ of the initial biomass has to be combusted with oxygen to drive the gasification process due to the temperature requirement [15]. This temperature requirement varies between $600-1000^{\circ} \mathrm{C}$ [32]. Additionally, one of the other disadvantages of conventional biomass gasification is the formation of tar which blocks and clogs the equipment. There have been some efforts to eliminate the tar formation with proper selection of materials, operating conditions and the design of the gasifier [32].

Solar-assisted gasification of biomass has advantages over the conventional process. The main advantages are the elimination of tar formation, even at temperatures as high as $1200^{\circ} \mathrm{C}$, and high and rapid conversion of biomass to syngas. At the National Renewable Energy Laboratory (NREL) of US, bluegrass was gasified with a maximum conversion of $95 \%$ and about $5 \%$ of the products were hydrocarbons, ash and char [33]. The resident times can be less than 5 seconds [33]. There is also a solar reactor design to combine solar biomass gasification and steam reformation [33].

\section{Concentrated solar reactors}

This section defines and compares different solar concentrators and gives examples of directly irradiated and indirectly heated solar reactors for the solar fuel production processes defined in the previous section. 


\subsection{Solar concentrators}

There are two main types of concentrated solar collectors, categorized depending on their optical configurations. First type is parabolic trough systems in which there is an absorber tube in the focal line of parabolic reflectors. Linear Fresnel reflectors can also be included in this type of concentrated solar collectors. Second type is point focus solar collectors which include dish systems and heliostats. Dish systems have a solar receiver located in the focal point of the paraboloidal concentrator, and heliostats direct sun light to a solar receiver located at the top of a solar tower. Figure 3 shows the schematic of each solar collector type. Before going into details of each collector type, some terms need to be defined.
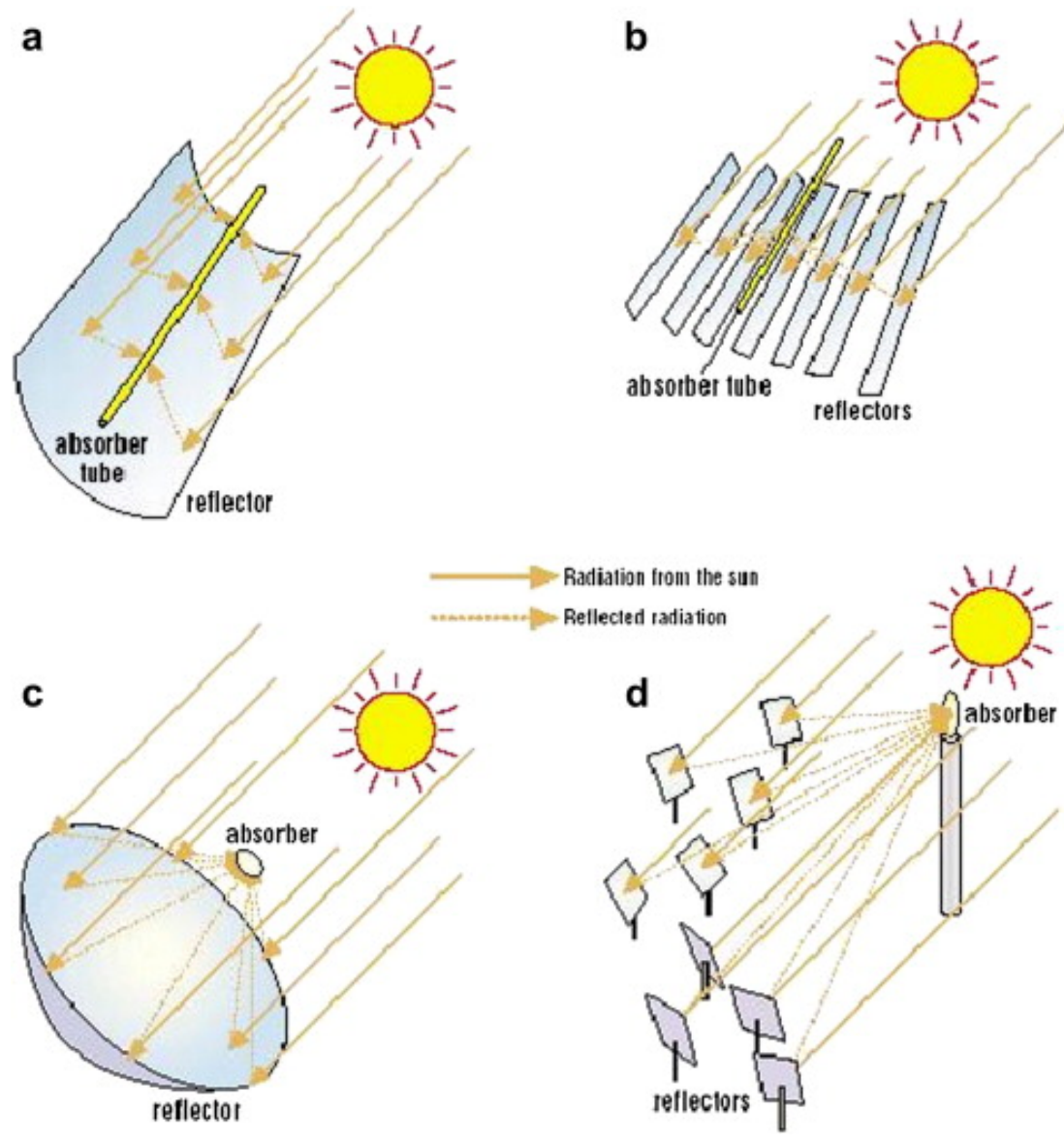

Figure 3. Solar concentrators, (a) parabolic trough, (b) linear Fresnel, (c) dish collectors, and (d) heliostats with solar tower [34]. 
Concentrating ratio is the ratio of the radiation intensity at the receiver by the radiation intensity received by the concentrator. Concentrating ratio plays an important role on the maximum achievable temperature at the receiver. Solar collector efficiency, $\eta$, is a product of Carnot efficiency, $\eta_{\text {Carnot }}$ and the receiver efficiency, $\eta_{\text {receiver }}$, as,

$$
\begin{aligned}
\eta & =\eta_{\text {Carnot }} \cdot \eta_{\text {receiver }} \\
& =\left(1-\frac{T_{o}}{T_{r e c}}\right)\left(\frac{\alpha \cdot G \cdot C-\varepsilon \cdot \sigma \cdot T_{r e c}^{4}}{G \cdot C}\right)
\end{aligned}
$$

where $T_{o}$ and $T_{\text {rec }}$ are the surroundings and receiver temperatures, respectively, $\alpha$ and $\varepsilon$ are the absorptivity and emissivity of the receiver, $G$ is the solar irradiation, $C$ is the concentrating factor and $\sigma$ is the Stefan-Boltzmann constant $\left(5.67 \times 10^{-8} \mathrm{~W} / \mathrm{m}^{2} \cdot \mathrm{K}^{4}\right)$. Figure 4 shows the solar collector efficiency as a function of receiver temperature when ambient temperature is $300 \mathrm{~K}$, absorptivity and emissivity are both 1, and the solar irradiation is $1000 \mathrm{~W} / \mathrm{m}^{2}$. The figure shows that higher thermal efficiencies and higher receiver temperatures can be obtained with increasing concentrating ratios. Therefore, the selection of solar concentrators mainly depends on the temperature requirement of the application.

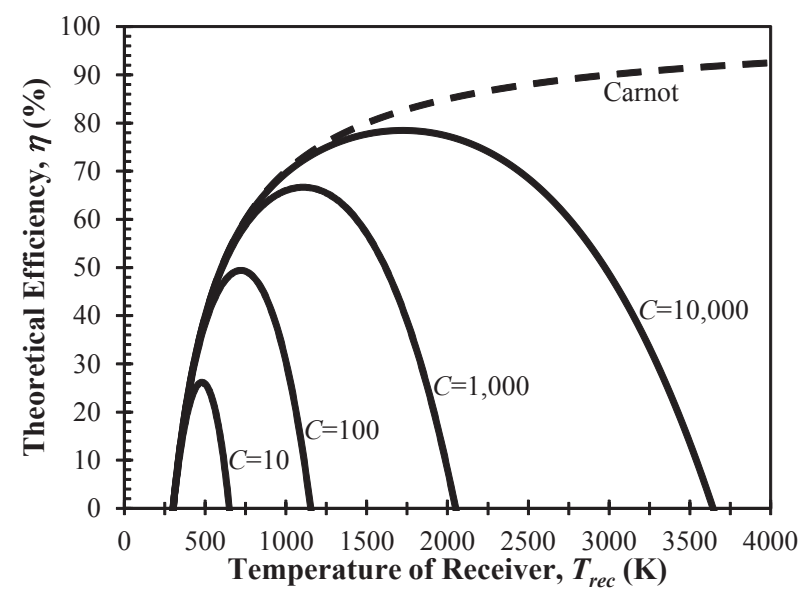

Figure 4. Theoretical solar reactor efficiency, $\eta$, as a function of receiver temperature, $T_{\text {rec }}$ for different concentrating ratios, $C$.

\subsubsection{Parabolic-trough systems}

Parabolic-trough collectors consist of several tubes interconnected in the focal line of highly reflective sheet material. These linearly connected tubes are generally referred as evacuated tubes since they consist of two concentric tubes whose annulus is vacuumed. The working fluid is circulated in the inner tube. The inner tubes are generally made of metals, and out- 
side of the inner tube has selective coating to increase the absorption and decrease the heat loss. The outer tubes are generally made of glass, and they can also have selective coatings.

Applications of parabolic-trough collectors can be divided into two sections depending on the temperature of application. The low temperature applications, varies from $100^{\circ} \mathrm{C}$ to $250^{\circ} \mathrm{C}$, include domestic hot water, space heating and heat-driven refrigeration [35]. Their concentrating ratios are between 15 and 20. The high temperature applications have temperatures up to $400^{\circ} \mathrm{C}$, concentrating ratios of 20 to 30 [35]. Theoretical limit for concentrating ratio can go up to 100 [2]. These collectors are mainly used in power plants that are driven by steam. In the parabolic trough collectors, the pressure within the inner tube can reach $10 \mathrm{MPa}$.

There are other configurations of cylindrical absorber tubes which are not commonly used [36-38]. One type has a circulation tube inside the inner cylinder which carries the working fluid. This circulation tube is attached to the inner tube with a cylindrical fin. In this type, the absorbing surface is the fin itself, not the inner tube. Another type cylindrical absorber has a delivery tube inside the inner tube, and the working fluid delivered by this delivery tube fills the space in the inner tube. In another tube type, working fluid fills the annulus [37].

These parabolic-trough collectors and other cylindrical absorber tubes may have diffuse or specular reflectors at their back. Diffuse reflectors are generally flat surfaces that cover the entire back of arrays of tubular collectors. However, specular reflectors have parabolic surfaces, and they cover the back of only one cylindrical absorber. If specular reflectors are used, the absorber tubes have to be in the reflector's focal line.

Line focus collectors are mounted with axes either in north-south or east-west direction. Hence, single axis tracking for this kind of collectors is sufficient to track the sun throughout the year. Collectors with axes in north-south direction track the sun from sunrise to sunset each day. Alternatively, collectors with axes in east-west direction track the sun seasonally. The spacing between each line of collectors in a solar farm with parabolic trough collectors is determined considering sun shadow line in the winter when the solar radiation comes with a larger azimuthal angle [38].

As an example, Nevada Solar One is in operation in Boulder City, Nevada, USA since 2007, covers 400 acres and has a capacity of 64 MW [39]. Figure 5 shows a picture of this power plant. Another and largest power plant with parabolic trough collectors is Solar Energy Generating Systems (SEGS) VIII-IX, built on approximately 240 acres and operating at 80 MW each near Harper Lake, California, USA. SEGS are also integrated with conventional natural gas turbines to operate at nights. It was reported that solar energy covers about $90 \%$ of the power production [40].

Another design is the absorber tubes with Fresnel reflectors. Fresnel reflectors that are mounted close to the ground direct and concentrate solar irradiation to the absorber tubes that are elevated at a higher level than reflectors. A secondary reflector on the back side of the absorber tube is also use to direct all the irradiation to the absorber tube. The main advantages of using Fresnel reflectors are that they have less wind load than the reflectors of 
parabolic trough collectors since these reflectors are located at a lower position, and no requirement for vacuum in the absorber tubes and for rotating joints [42]. However, the main disadvantage of Fresnel reflectors is that they have lower concentrating ratios than parabolic trough collectors [43].

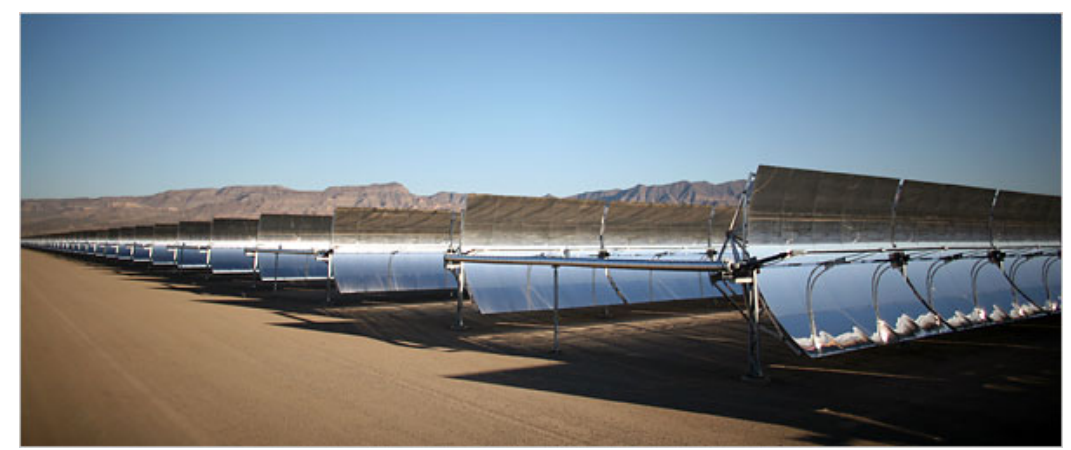

Figure 5. Parabolic-trough collectors in Nevada Solar One power plant [41].

In Calasparra, Spain, Novatec Biosol built a power plant with 28 rows of linear Fresnel reflectors that produces $30 \mathrm{MW}$ of electrical power in an area of nearly 200 acres. Figure 6 shows a picture of this power plant. The power plant uses steam, and the temperature and pressure of the steam produced reach to $270^{\circ} \mathrm{C}$ and 55 bars, respectively [44, 45].

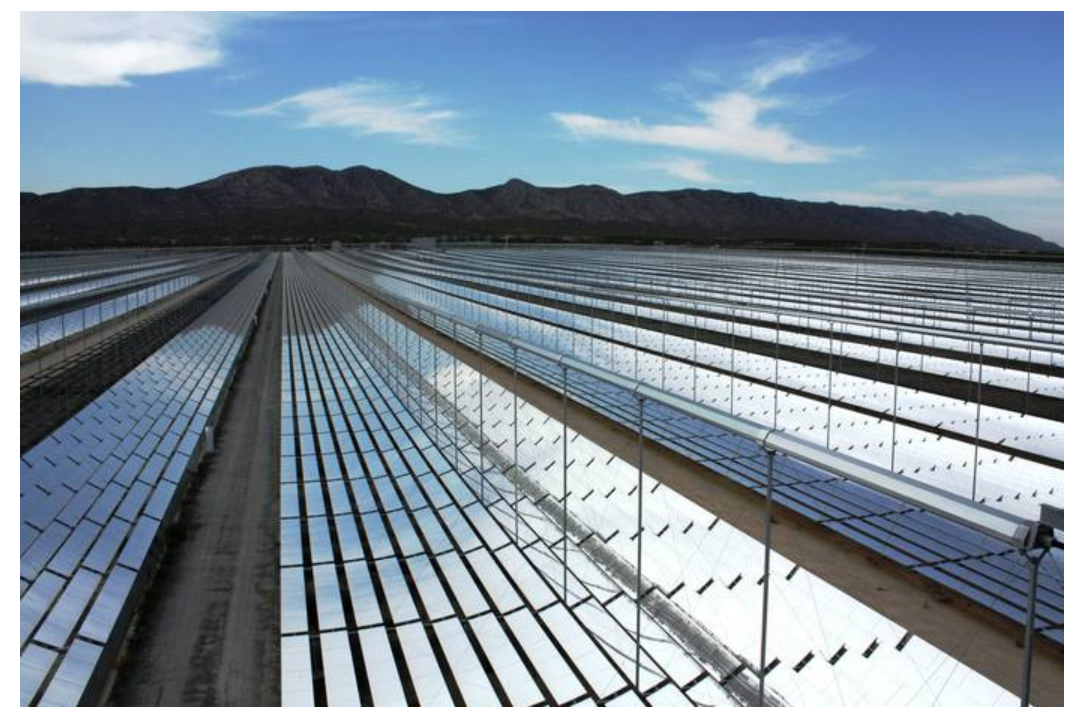

Figure 6. Linear Fresnel reflectors in the power plant Thermosolar Power Plant (PE2) in Spain [46]. 


\subsubsection{Point focus collectors}

Parabolic dish collectors concentrate sunlight to the focal point of the parabolic reflectors. These collectors have two-axis sun tracking system. In the focal point of the parabolic reflector, a working fluid is heated directly to a maximum temperature of about $1000 \mathrm{~K}$ [47]. This working fluid is generally used to drive a Stirling engine or a gas turbine to produce electricity. The typical parabolic dish collectors have a diameter of 5 to $10 \mathrm{~m}$, and each can produce up to $0.4 \mathrm{MW}[47,48]$. The concentrating ratios parabolic dish collectors vary between 1,000 and 10,000 [2]. The reflector is usually made of silver or aluminum coated glass. This kind of collectors can be used in applications with relatively low power requirement in remote areas.

One of the first examples of power plant using parabolic dish collectors was supposed to be Maricopa Solar Plant in Arizona, USA before its contractor company was announced bankruptcy in 2011. Figure 7 shows a picture of this power plant. This power plant consists of 60 parabolic dish collectors that heat the hydrogen to drive Stirling engines. The power plant has a capacity of $1.5 \mathrm{MW}$. This technology is not commercially operational and available in large scale power production.

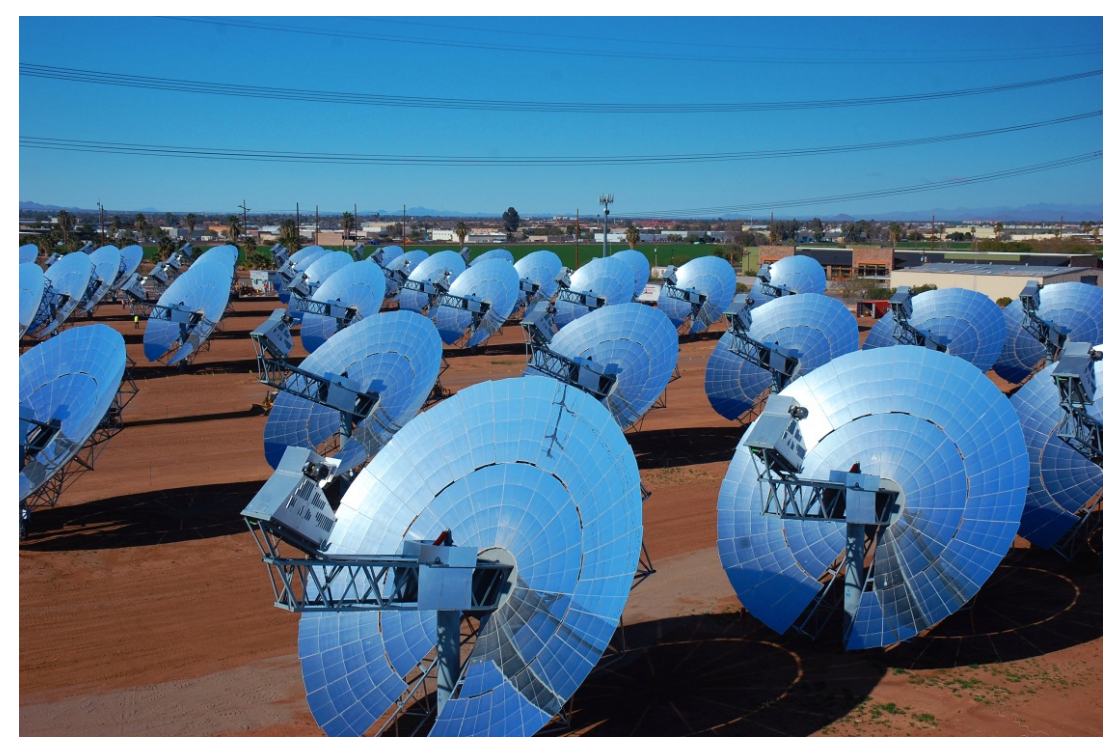

Figure 7. Parabolic dish collectors in Arizona, USA [49].

Some solar thermal power plants use arrays of heliostats which are sun-tracking flat mirrors. These mirrors or heliostats with two-axis tracking system direct solar irradiation to the receiver located at the top of a tower on a concrete support. In order to direct the sunlight to the receiver with sufficient accuracy all the times, a motor drive system with a large gear reduction is necessary [50]. Due to the presence of the tower, these power plants are sometimes referred as power 
tower systems. Concentrating ratios for these systems vary between 500 and 5000 [2], and the temperature at the receiver can exceed $2000 \mathrm{~K}$ depending on the concentrating ratio. These power plants can be used for converting solar energy to chemical energy, such applications include reduction of zinc oxide and coal gasification [51].

Throughout the technological development of heliostats, their sizes become larger and larger in order to decrease the production cost since their cost is a strong function of production rate. Although the initial development of heliostats started in 1975, one of the first prototypes of heliostats in 1980s by Sandia Labs, USA had an area of $37 \mathrm{~m}^{2}$ [52]. Currently, Planta Solar (PS) 20 solar power plants use heliostats with each of their area as $120 \mathrm{~m}^{2}$ [53]. Another improvement in the development of heliostats is the material choice. Glass mirrors with steel support structure are being replaced by silver polymer mirrors with silver-steel alloy structure in order to increase the structural durability and reduce the weight of heliostats [52]. Some designs also have circular mirrors instead of rectangular ones to reduce stress on the support structure.

The Crescent Dunes Solar Energy Project in Tonopah, Nevada, USA will be an example to the central tower power plants once it is completed late 2013. It will be built on approximately 1600 acres, and it will produce $110 \mathrm{MW}$ of electrical power using molted salt as a phase changing storage medium [54]. As another example, PS 20 which is operational since 2009 has a cavity receiver at the top of a 165-m tower. Figure 8 shows the picture of this power plant. It heats up water in the cavity, and steam reaches an outlet temperature of maximum $550 \mathrm{~K}$. This solar power plant consists of 1255 heliostats with a total area of 30 acres. The solar power plant is backed up with natural gas burnt conventional turbine, and the total power production is 20 MW. PS 20 power tower is cooled with water which is generally replaced by air cooling if the power plant is built on deserts due to lack of water resources. The cooling is necessary for the materials used in the power towers.

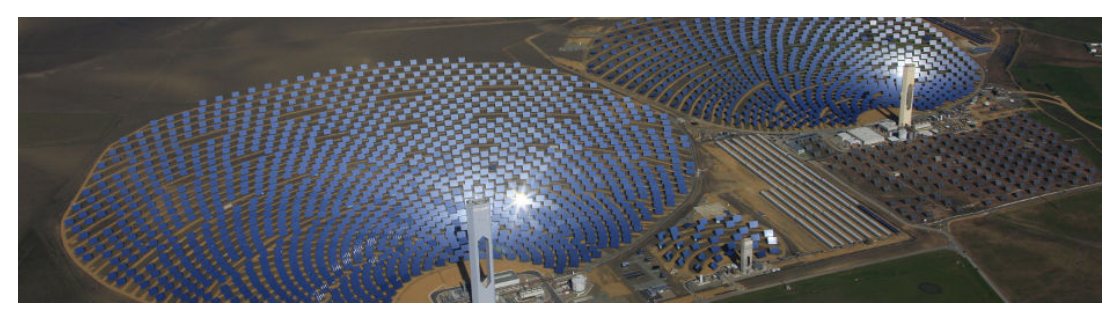

Figure 8. PS 10 (back) and PS 20 (front) solar thermal power plants with heliostats with solar towers [55].

To reach the necessary temperatures for the solar fuel production methods given in the previous section, tower or dish type collectors should be used. For further reference, a review paper on the volumetric receivers for the concentrating solar thermal power plants discussed different designs from the projects of the last 3 decades [56]. Another good review was done on comparison of parabolic trough, dish systems, solar towers and tubular systems with Fresnel reflectors by Pavlovic et al. [57]. 


\subsection{Solar reactors}

In this section, different solar reactors that were designed for fuel production using concentrated solar energy are discussed and compared in terms of their operating conditions and design parameters. Depending on the reactor design, these reactors were fed feedstock with or without solid particles to perform hydrolysis, cracking, gasification, etc. These particles not only allowed a more uniform temperature distribution inside the reactor, but also helped the reactor to reach higher temperatures faster. These particles also acted as additional reaction sites due to their high surface are to volume ratios. In some designs, feedstock was diluted with some inert gas, such as Argon, to increase the produced fuel yield. An auxiliary gas was also fed to prevent particle deposition on the window surface. In some designs, reactors were supplemented with a cooling system for products to prevent them recombine.

In general, the solar energy is transformed into thermal energy in the structure of volumetric receivers. In some designs, solar energy directly heats the feedstock in the reactor which is referred as directly irradiated solar reactors. Additionally, some of these receivers have a porous metal or ceramic absorber to be heated by solar energy. Metal absorbers can be heated up to $1000^{\circ} \mathrm{C}$ whereas $\mathrm{SiC}$ absorbers can reach $1500^{\circ} \mathrm{C}$ as maximum temperatures. Then, this thermal energy is transferred to a working fluid that passes through the porous absorber. This kind of reactors is referred as indirectly heated solar reactors.

\subsubsection{Directly irradiated solar reactors}

In this section, examples of directly irradiated solar reactors are presented with their design parameters, temperature and pressure allowances, their power outputs and their solar fuel production rates. These examples are selected to give a wide range of applications and designs.

Maag et al. [17] tested a $5 \mathrm{~kW}$-prototype of a solar reactor seeded with particles for thermal cracking of methane. The cylindrical reactor was $200 \mathrm{~mm}$ in length and $100 \mathrm{~mm}$ in diameter. It had a $60 \mathrm{~mm}$ aperture area. The concentrator was covered with a $240 \mathrm{~mm}$-diameter quartz window as shown in Figure 9. In their experiments, they used a sun-tracking parabolic concentrator that has a diameter of $8.5 \mathrm{~m}$ and could reach a concentrating factor up to 5000 suns. They tested the reactor in the temperature range from 1300 to $1600 \mathrm{~K}$ with a concentrating factor of 1720 suns. They varied the volume fraction of carbon in the range of 0 to $7.2 \times 10^{-5}$ and gas inlet flow rate in the range of 8.6 to $15.61 / \mathrm{min}$. They reported maximum methane-to-hydrogen conversion of $95 \%$ at a residence time less than 2 seconds, and an experimental solar-to-chemical energy conversion efficiency of $16 \%$, whereas their theoretical prediction of the same conversion efficiency was $31 \%$.

Yeheskela and Epstein [58] developed and tested 10-kW particle-seeded solar chemical reactor for producing hydrogen and carbon nanotubes from methane. They used iron pentacarbonyl and ferrocene as catalysts to produce multi-walled carbon nanotubes. The reactor was $300 \mathrm{~mm}$ in length, and the quartz window which covered the reactor as shown in Figure 10 was $200 \mathrm{~mm}$ in diameter. Additionally, He was used as a screen protector gas to eliminate the particle deposition on and near the window, and $\mathrm{N}_{2}$ was used as a tornado generator gas. The average reported temperature within the reactor core was $1450^{\circ} \mathrm{C}$. 


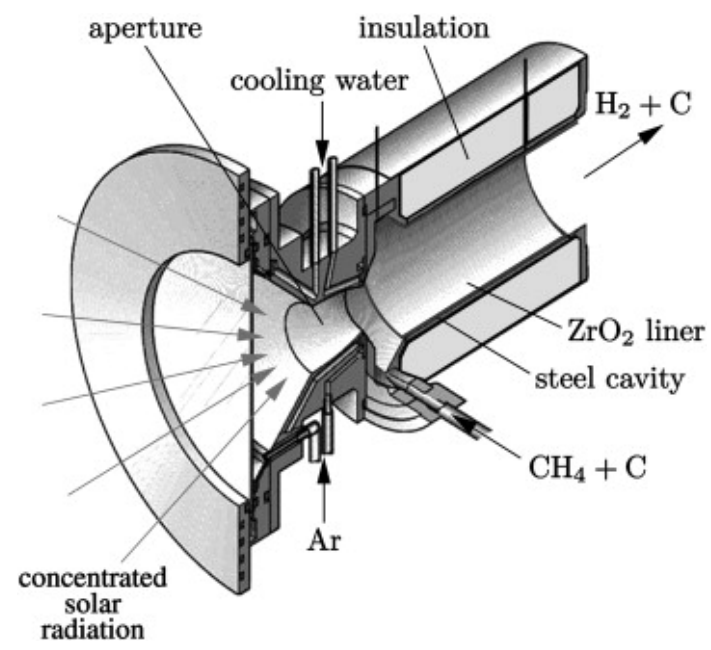

Figure 9. Schematic of design of Maag et al. [17].

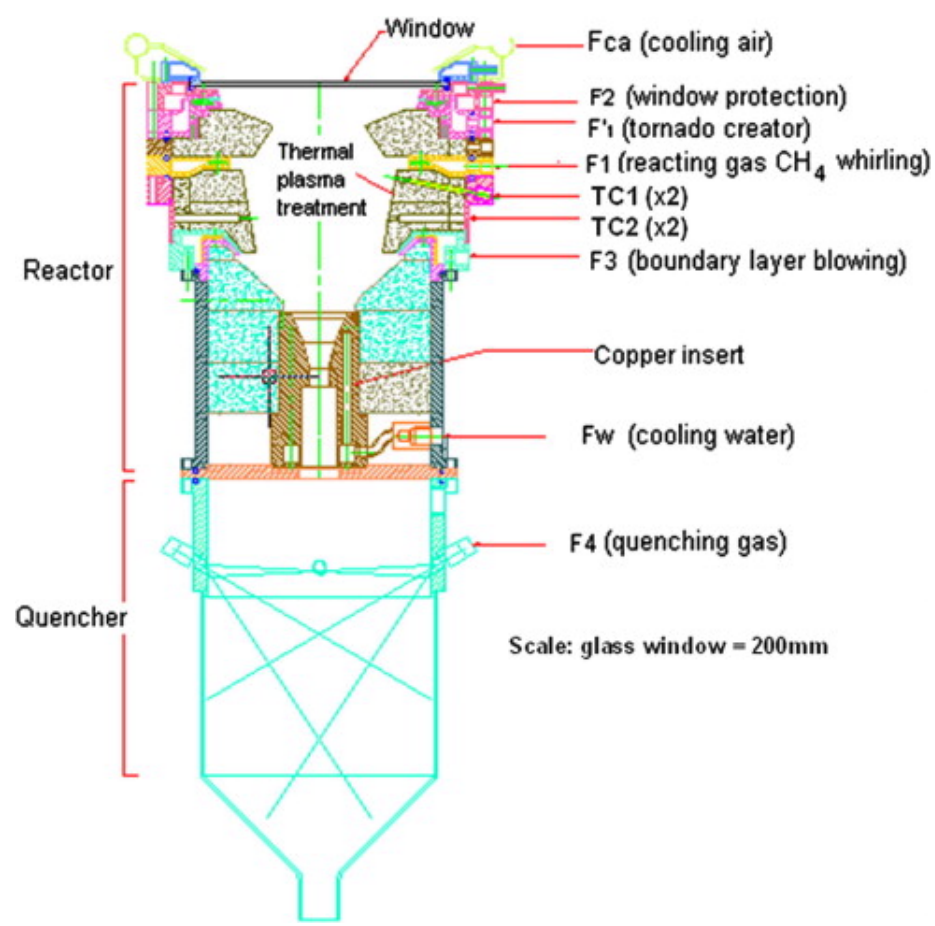

Figure 10. Schematic of design of Yeheskela and Epstein [58]. 
Abanades and Flamant [59] designed nozzle-type directly-irradiated solar reactor for methane cracking. They used a graphite nozzle with an inner diameter of $10 \mathrm{~mm}$ and a length of $65 \mathrm{~mm}$. The schematic of the proposed design is shown in Figure 11. The reactor walls were made of stainless steel, and they were water cooled for their durability. Additionally, the products were also cooled to eliminate recombination of products [60]. The obtained conversion of methane to hydrogen exceeded $95 \%$ in molar basis, while the rest of the by-products were $\mathrm{C}_{2} \mathrm{H}_{2}, \mathrm{C}_{2} \mathrm{H}_{4}$ and $\mathrm{C}_{2} \mathrm{H}_{6}$. With a direct normal irradiation of $980 \mathrm{~W} / \mathrm{m}^{2}$, the temperature of graphite nozzle had a maximum temperature of $1385^{\circ} \mathrm{C}$, while their model estimated the maximum wall temperature as $1890 \mathrm{~K}$.

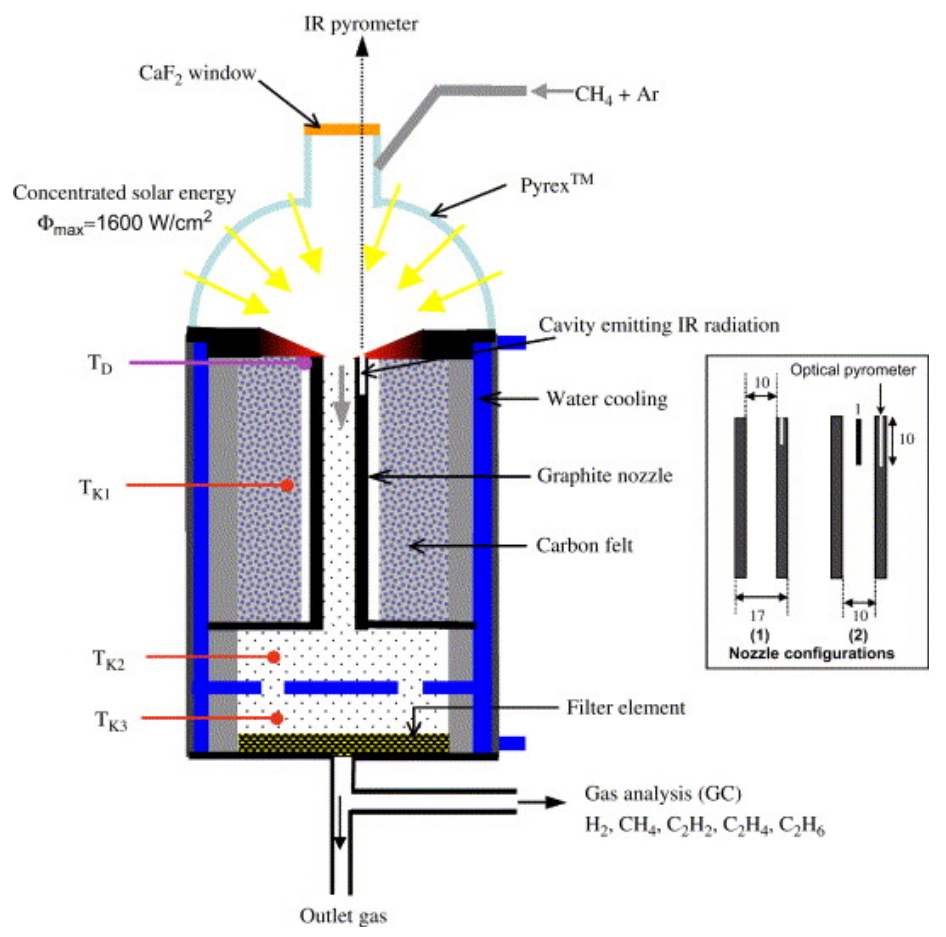

Figure 11. Schematic of design of Abanades and Flamant [59].

Klein et al. [61] investigated the performance of directly irradiated solar methane cracking process with and without $\mathrm{CO}_{2}$ present in the reactor. The reactor, as shown in Figure 12, had a diameter of $160 \mathrm{~mm}$, a length of $266 \mathrm{~mm}$ and an aperture diameter of $60 \mathrm{~mm}$. The gas exit temperatures with $\mathrm{CO}_{2}$ only (no methane) in the reactor were in the range from 1000 to $1250^{\circ} \mathrm{C}$. Additionally, the exit temperatures were in the range from 1100 to $1450^{\circ} \mathrm{C}$ with $\mathrm{CO}_{2}$ and methane, when the $\mathrm{CO}_{2}$ and methane molar ratio were varied from 1:1 to 1:6. Overall, the experimental results were similar to the studies where no $\mathrm{CO}_{2}$ was introduced into the reactor. Moreover, when the reactor was fed with $\mathrm{CO}_{2}$ and carbon black and the gas exit 
temperature reached $1000^{\circ} \mathrm{C}, 20 \%$ of carbon particles reacted with $\mathrm{CO}_{2}$. When the exit gas temperature was increased to $1350^{\circ} \mathrm{C}$, about $70 \%$ of the carbon particles reacted with $\mathrm{CO}_{2}$.

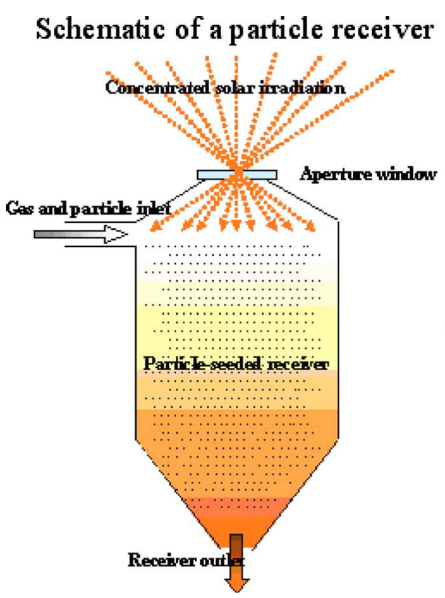

\section{Solar receiver used in experiments}

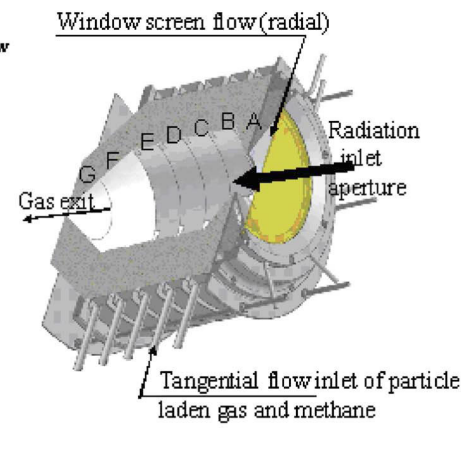

Figure 12. Schematic of design of Klein et al. [61].

Z'Graggen et al. [62] designed a 5-kW prototype reactor for steam-gasification of petroleum coke using concentrated solar energy. The reactor had a 5-cm diameter aperture which was covered by 3-mm-thick quartz window. The window was cooled by oil, and swept by an inert gas to prevent particle accumulation on the window. The solar concentrating ratio was about 5000, and the maximum temperature in the reactor was about $1800 \mathrm{~K}$. The walls of the cavity were covered with $\mathrm{Al}_{2} \mathrm{O}_{3}$ and insulated from the backside with $\mathrm{Al}_{2} \mathrm{O}_{3}-\mathrm{ZrO}_{2}$. Figure 13 shows the design of $Z^{\prime}$ Graggen et al. [62]. As a result of the steam-gasification of petroleum coke, $\mathrm{H}_{2}, \mathrm{CO}, \mathrm{CO}_{2}$ and $\mathrm{CH}_{4}$ were produced with a chemical conversion ratio of $87 \%$. The overall solar-to-chemical conversion efficiency was about $9 \%$.

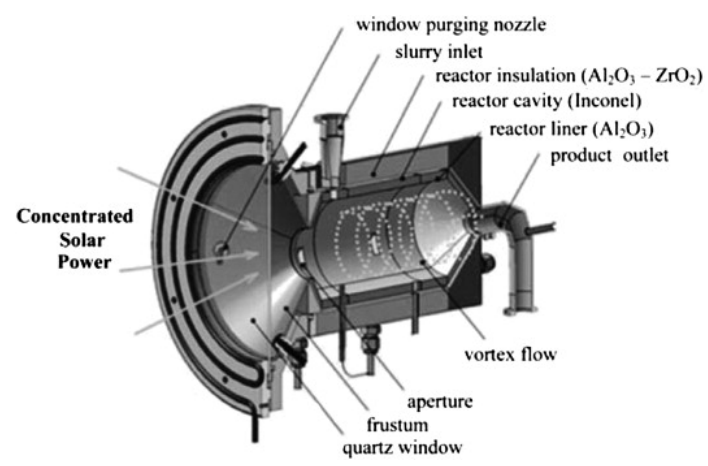

Figure 13. Reactor design of Z'Graggen et al. [62]. 


\subsubsection{Indirectly heated solar reactors}

Directly irradiated solar reactors work with high conversion efficiencies. However, they have problems, such as accumulation of particles on the window. In order to overcome this problem and the need for inert gas feeding, indirectly heated solar reactors are alternatively introduced. This section gives some design examples of indirectly heated solar reactors for different solar fuel production methods.

Gordillo and Belghit [63] modeled the reaction kinetics without pyrolysis using finite volume analysis in a two-phase biochar solar gasification reactor with a bubbling fluidized bed as shown in Figure 14. Bubbling was used to introduce fluidizing gases to the reactor. They found that concentrating solar energy and high gas flow rates affected the temperature distribution within the packed bed. Therefore, a uniform temperature distribution could not be obtained which adversely affected the reaction kinetics. Additionally, they showed that although energy conversion efficiency $(\eta)$, defined as in Equation (10), could be as high as $55 \%$, it decreased with increasing the steam velocity or the bed temperature [64].

$$
\eta=\frac{\dot{m}_{\text {product }} L H V_{\text {product }}}{\dot{Q}_{\text {solar }}+\dot{m}_{\text {feedstock }} L H V_{\text {feedstock }}}
$$

where $\dot{m}$ and $L H V$ refer to the mass flow rate and lower heating value, $\dot{Q}_{\text {solar }}$ is the solar irradiation, subscripts product and feedstock denote gaseous products and fed feedstock, respectively.

According to Hathaway et al. [65], problems with the preceding reactor designs had poor heat transfer characteristics [63], formation of ash and tar which block the radiative heat transfer and insulate the reaction zone, and intermittency of solar energy. Hathaway et al. [65] investigated the effects of using molten salt on the reaction kinetics in solar gasification of biomass. For the analysis of pyrolysis which occurs before gasification, they prepared tablets using microcrystalline cellulose, and for the analysis of steam gasification, they used tablets of wood charcoal powder. They carried out a series of experiments in the temperature range from 1100 to $1250 \mathrm{~K}$ to show the effects of molten alkali carbonate salts (lithium, sodium and potassium carbonate) on reaction rates using the experimental setup shown in Figure 15. They showed that introducing molten salts increased the rate of pyrolysis by $74 \%$ and increased the rate of gasification by more than an order of magnitude since molten salts acted as a heat transfer medium for gasification which ended up with more uniform temperature distribution within the solar reactor. On the contrary to the other studies, the catalytic effect of molten salt on pyrolysis was not observed for the reason that pyrolysis happened rapidly, and then gasification occurred. However, the catalytic effect of molten salt on gasification was observed. Introducing the molten salt increased the pre-exponential factor (i.e., rate of reaction in steady state process) by 24.4 times and increased the activation energy by about $4 \%$. Additionally, using molten salt avoids the tar production (as a by-product of uncatalyzed gasification, occurs especially on startup), and molten salts can act as an energy storage unit to overcome the intermittency effect of solar energy. 
(a)

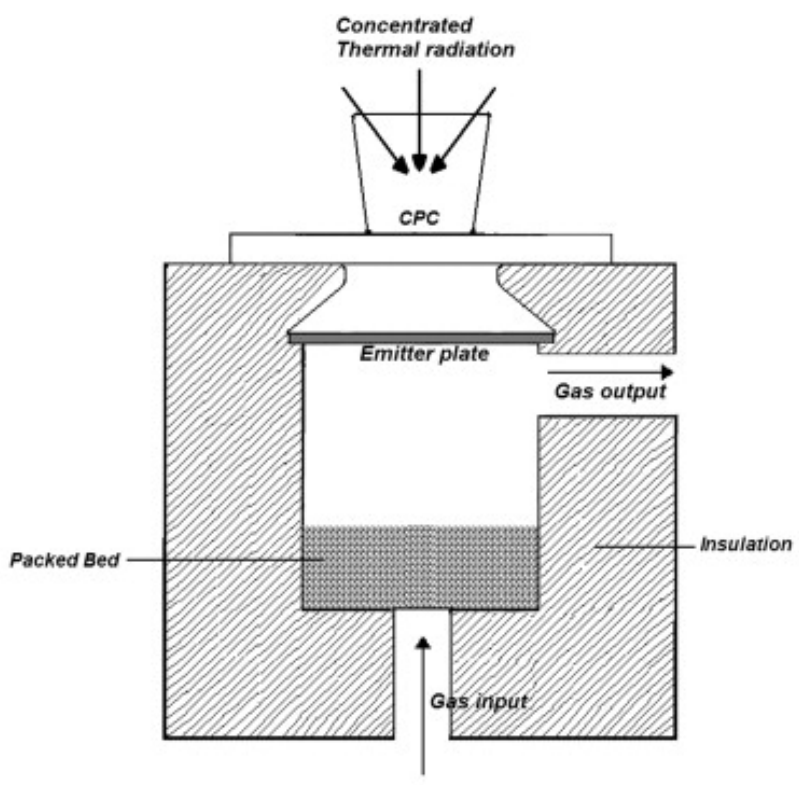

(b)

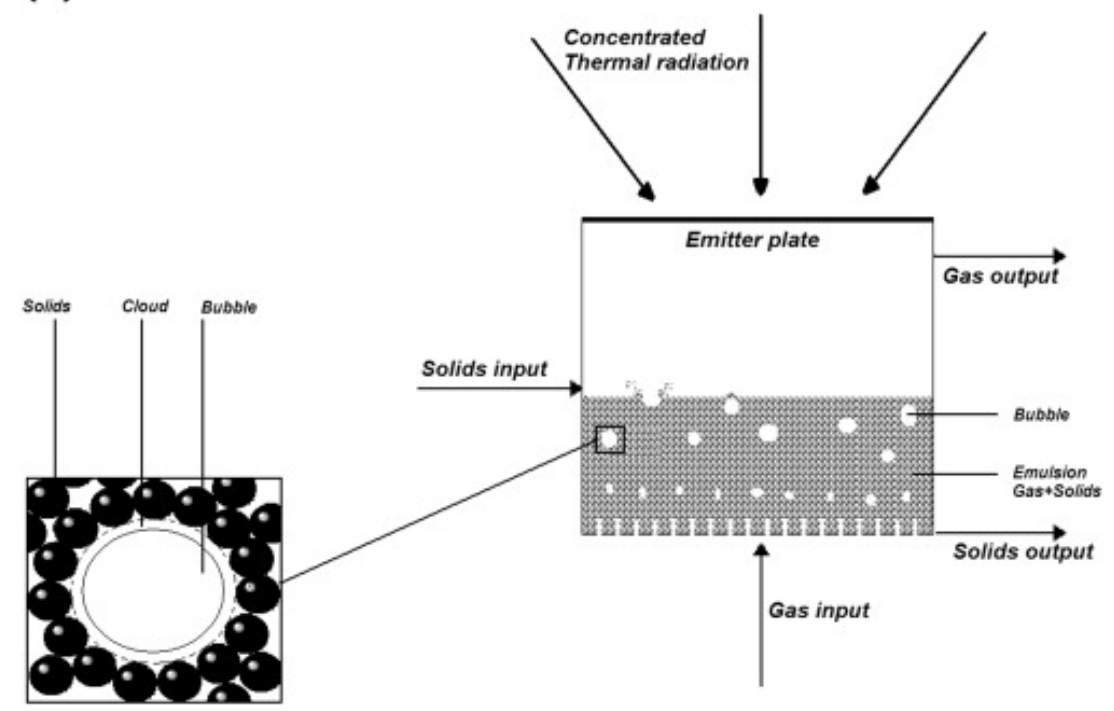

Figure 14. Model of Gordillo and Belghit [63]. 


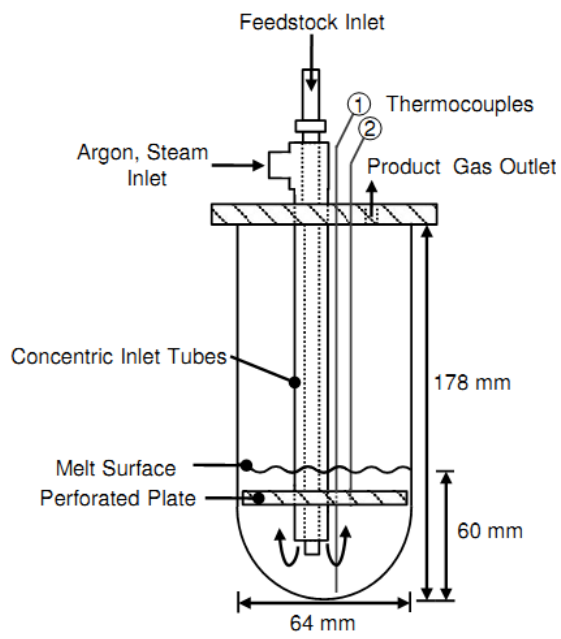

Figure 15. Experimental setup of Hathaway et al. [65].

Rodat et al. [66] developed a $10 \mathrm{~kW}$ tubular reactor prototype, which was indirectly heated, for methane cracking as shown in Figure 16. They used a graphite cubic cavity as a receiver and a quartz window. The quartz window was swept by nitrogen which prevented $\mathrm{O}_{2}$ to enter the cavity. The reactor reached $2070 \mathrm{~K}$, and the products included $\mathrm{C}_{2} \mathrm{H}_{2}$ with maximum mole fraction as $7 \%$. As given in Equation (7), $\mathrm{C}_{2} \mathrm{H}_{2}$ is the last step of $\mathrm{H}_{2}$ and carbon black evolution. The graphite cavity was purged by $\mathrm{N}_{2}$. For this configuration, the reactor required about 4000 seconds to reach the required temperature of $1800 \mathrm{~K}$ when the experiment started at $300 \mathrm{~K}$ under the direct normal irradiance of $1000 \mathrm{~W} / \mathrm{m}^{2}$ [67].

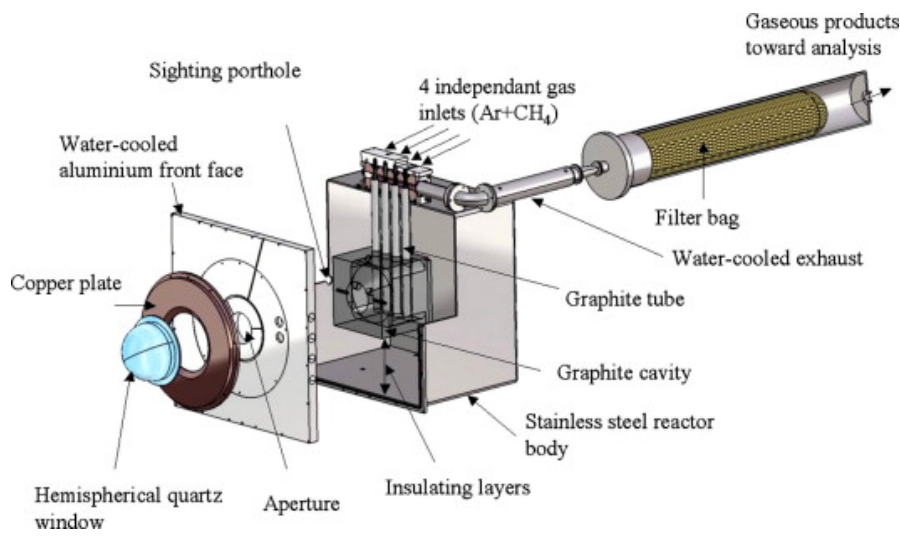

Figure 16. Schematic of design of Rodat et al. [66]. 
Lichty et al. [69] designed and analyzed the thermal characteristics of a cavity reactor prototype for solar-thermal biomass gasification as shown in Figure 17. The maximum recorded temperature was $1660 \mathrm{~K}$ on the central tube under $7.5 \mathrm{~kW}$ power input. They quantified the reacted biomass based on $\mathrm{CO}$ and $\mathrm{CO}_{2}$ as these gases showed the ratio of reactants underwent a complete reaction, and the authors reported an average biomass-to- $\mathrm{CO}$ and $\mathrm{CO}_{2}$ conversion as $58.4 \%$. The residence time was about 4 seconds. They also compared the syngas production of grass and lignin pyrolysis and cellulose gasification using mass spectrophotometer.

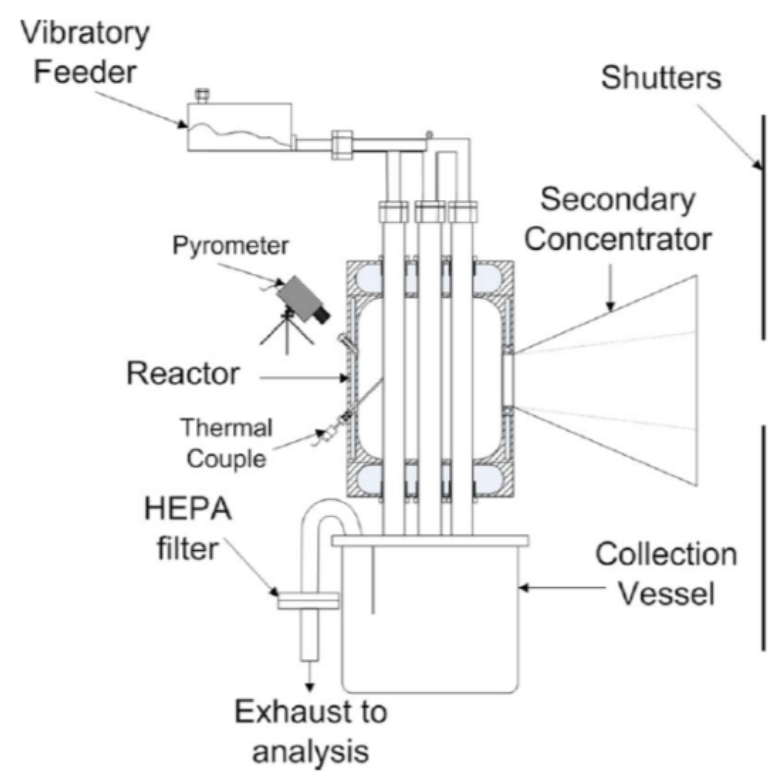

Figure 17. Reactor design of Lichty et al. [69].

In the design of the German Aerospace Center for directly irradiated solar reactor to reform natural gas is given in Figure 18, porous ceramic absorber coated with Rh catalyst was used [12]. A concave quartz window was also mounted on the concentrating solar collector [12]. The operating conditions were chosen as $1400^{\circ} \mathrm{C}$ and 3.5 bars, and a volumetric flow rate of $3.81 / \mathrm{min}$ with $5 \%$ methane in argon $[70,71]$. 


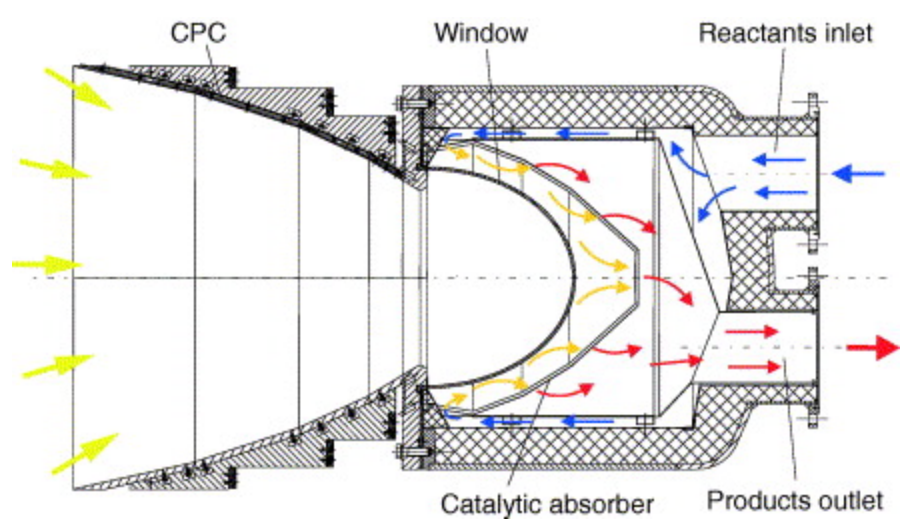

Figure 18. Design of the German Aerospace Center for natural gas reforming [12].

Maag et al. [72] simulated the performance of a $10 \mathrm{MW}$ commercial-size reactor. The reactor consisted of four graphite absorber tubes with an outer diameter of $24 \mathrm{~mm}$ placed in a $0.2 \mathrm{~m}$ cubic graphite cavity as shown in Figure 19. The graphite cavity had an aperture of diameter $9 \mathrm{~mm}$ which was covered by quartz window. They predicted $100 \%$ methane-to-hydrogen conversion when flow rate of methane was $0.7 \mathrm{~kg} / \mathrm{s}$ at a reactor exit temperature of $1870 \mathrm{~K}$. Spectral properties of quartz window were estimated using a band model, and view factors were calculated using Monte Carlo ray-tracing method. The energy balance for the overall system was solved with finite volume method. The results showed that it was possible to increase solar-to-chemical energy conversion efficiency from $42 \%$ to $60 \%$ when the outlet temperature was lowered to $1600 \mathrm{~K}$ and, subsequently, the methane flow rate was doubled, but then quality of carbon black as a product would be poorer.

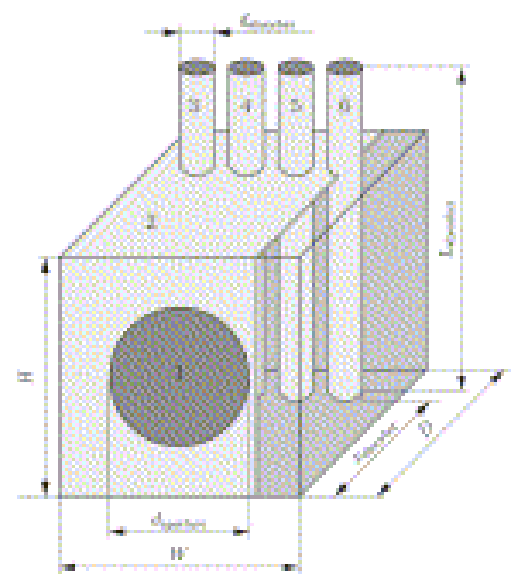

Figure 19. Schematic of design of Maag et al. [72]. 
Osinga et al. $[73,74]$ designed 5-kW indirectly heated solar reactor for the reduction of $\mathrm{ZnO}$. There were two different versions of the reactor. First one had the inner cavity made of graphite, and the second one had the inner cavity made of SiC. Figure 20 shows the second type, reactor with $\mathrm{SiC}$ absorber. Both reactors could reach temperature of $1700 \mathrm{~K}$ in about 80 minutes after the solar energy was input to the reactor. The reactor with graphite absorber had a vacuum pressure of 10 mbar whereas the pressure inside the reactor with $\mathrm{SiC}$ absorber was kept at 1 bar. $\mathrm{ZnO}$ and $\mathrm{C}$ mixture was reduced to $\mathrm{Zn}, \mathrm{CO}$ and $\mathrm{CO}_{2}$ from which $\mathrm{Zn}$ can be reacted with water to produce $\mathrm{ZnO}$ and $\mathrm{H}_{2}$ as in Equation (3) [75].

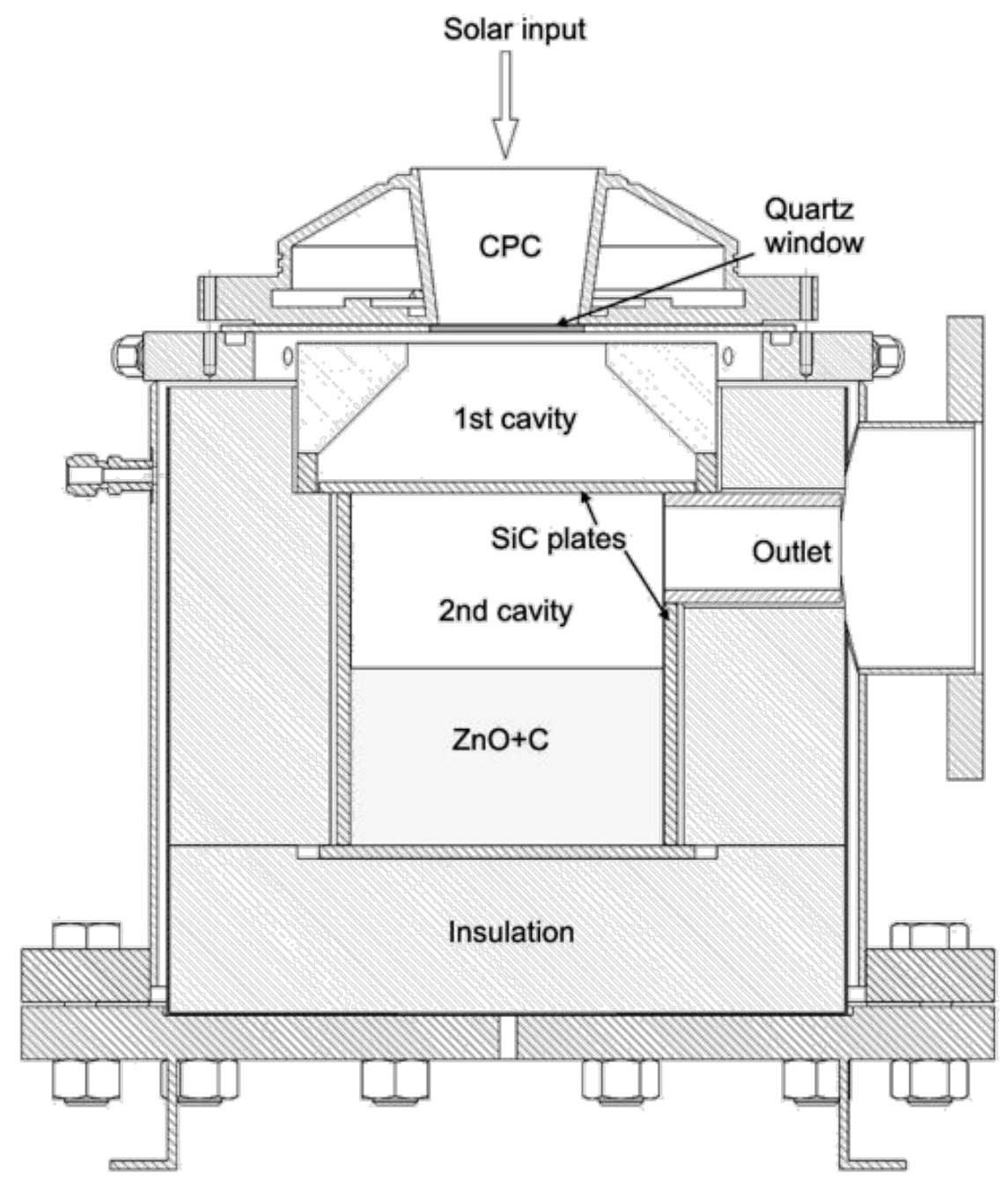

Figure 20. Reactor design of Osinga et al. [73]. 
The reactor with $\mathrm{SiC}$ absorber was scaled up to a capacity of $300 \mathrm{~kW}$ and operated by Wieckert et al. [76] under the EU project, called SOLZINC. They used solar tower with heliostats to deliver concentrated solar power of $300 \mathrm{~kW}$ to the volumetric reactor. The second cavity where the mixture of $\mathrm{ZnO}$ and $\mathrm{C}$ was present reached to maximum temperature of nearly $1500 \mathrm{~K}$, and overall ZnO-to-Zn conversion reached 95\% with a Zn production of $50 \mathrm{~kg} / \mathrm{h}$.

Piatkowski et al. [31, 77] designed a 5-kW indirectly heated solar reactor with packed bed for solar steam-gasification. Figure 21 shows the reactor design of Piatkowski et al. The authors used different carbonecous feedstock, such as African coal, sludge and charcoal. Beech charcoal gave the maximum solar-to-chemical conversion efficiency of $29 \%$ at a temperature of nearly $1500 \mathrm{~K}$. The solar reactor has two cavities separated an emitter plate made of SiCcoated graphite. The aperture diameter was $6.5 \mathrm{~cm}$ which was followed by a 3-mm-thick quartz window. The walls of the lower cavity was also covered by $\mathrm{SiC}$, and insulated by $\mathrm{Al}_{2} \mathrm{O}_{3}-\mathrm{SiO}_{2}$. The reactor received the concentrated solar energy with concentrating ratios up to 3000 , and the maximum temperature measured in the upper cavity was about $1700^{\circ} \mathrm{C}$.

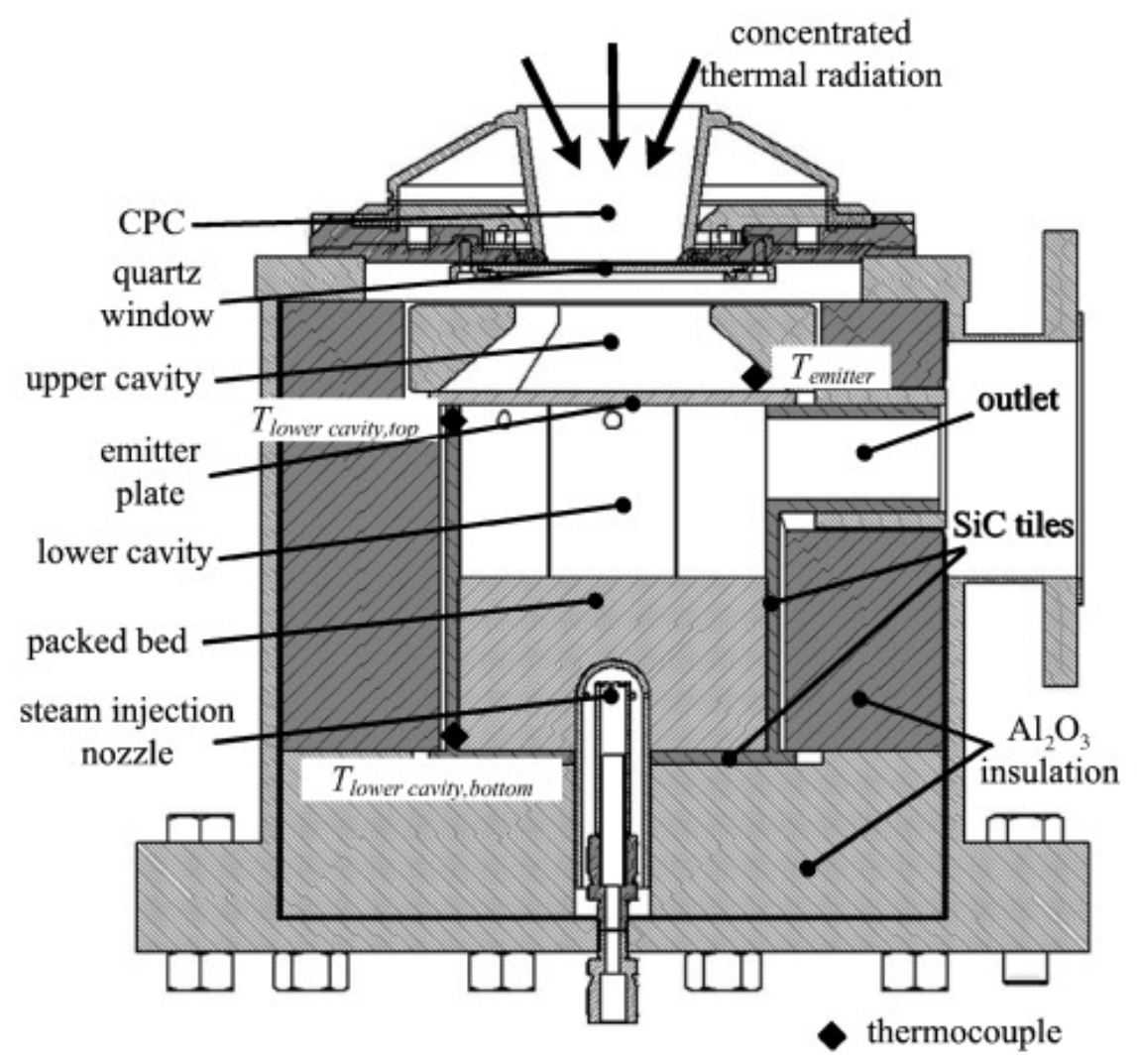

Figure 21. Reactor design of Piatkowski et al. [31, 77]. 
Summary of the operating conditions of the discussed designs for methane cracking is given in Table 3.

\begin{tabular}{|c|c|c|c|c|c|c|}
\hline Reference & $\begin{array}{c}\text { Maximum } \\
\text { Temperature }\left({ }^{\circ} \mathrm{C}\right)\end{array}$ & $\begin{array}{l}\text { Inlet } \mathrm{CH}_{4} \\
\text { Dilution } \\
\text { (\%vol.) }\end{array}$ & $\begin{array}{c}\text { Reactor } \\
\text { Dimensions } \\
(\mathrm{mm})\end{array}$ & $\begin{array}{c}\text { Aperture } \\
\text { Diameter } \\
(\mathrm{mm})\end{array}$ & $\begin{array}{l}\text { Inlet Flow } \\
\text { Rate(I/min) }\end{array}$ & $\begin{array}{l}\text { Catalytic or Fed } \\
\text { Conversion }\end{array}$ \\
\hline \multicolumn{7}{|c|}{ Directly Irradiated Solar Reactors } \\
\hline Maag et al. [17] & 1327 & 6-30 (in Argon) & $\begin{array}{l}100 \text { (diameter) } \\
200 \text { (length) }\end{array}$ & 60 & $8.6-15.6$ & $\begin{array}{l}\text { Carbon black } \\
\text { seeded }\end{array}$ \\
\hline $\begin{array}{l}\text { Yeheskela and } \\
\text { Epstein [58] }\end{array}$ & 1450 & 98 (in catalysts) & $\begin{array}{c}200 \text { (diameter) } \\
300 \text { (length) }\end{array}$ & 200 & $5-9.7$ & $\begin{array}{c}\text { Flow with } \mathrm{Fe}(\mathrm{CO})_{5} \\
\qquad \mathrm{Fe}\left(\mathrm{C}_{5} \mathrm{H}_{5}\right)_{2}\end{array}$ \\
\hline $\begin{array}{l}\text { Abanades and } \\
\text { Flamant [59, } \\
60]\end{array}$ & 1110 & 11-20(in Argon) & $\begin{array}{c}10 \text { (diameter) } 65 \\
\text { (length) }\end{array}$ & 10 & 0.9 & $\begin{array}{l}\text { No particle } \\
\text { feeding }\end{array}$ \\
\hline Klein et al. [61] & 1471 & $\begin{array}{c}\text { 10-24 (in Argon } \\
\text { or } \mathrm{CO}_{2} \text { ) }\end{array}$ & $\begin{array}{c}160 \text { (diameter) } \\
266 \text { (length) }\end{array}$ & 60 & $37-60$ & $\begin{array}{c}\text { Carbon black } \\
\text { seeded }\end{array}$ \\
\hline \multicolumn{7}{|c|}{ Indirectly Heated Solar Reactors } \\
\hline Rodat et al. [66] & 1800 & $\begin{array}{l}\text { 10-20 (in } \\
\text { Argon) }\end{array}$ & $\begin{array}{c}18 \text { (tube } \\
\text { diameter) } 200 \\
\text { (cube side) }\end{array}$ & 90 & - & $\begin{array}{l}\text { No particle } \\
\text { feeding }\end{array}$ \\
\hline $\begin{array}{l}\text { German } \\
\text { Aerospace } \\
\text { Center [12] }\end{array}$ & 1400 & 5 (in Argon) & - & - & 3.8 & $\begin{array}{l}\text { Reactor walls with } \\
\text { Rh }\end{array}$ \\
\hline Maag et al. [72] & 1600 & $\begin{array}{l}10-20 \text { (in } \\
\text { Argon) }\end{array}$ & $\begin{array}{c}24 \text { (tube } \\
\text { diameter) } 200 \\
\text { (cube side) }\end{array}$ & 9 & $10-48$ & $\begin{array}{l}\text { No particle } \\
\text { feeding }\end{array}$ \\
\hline
\end{tabular}

Table 3. Operating Conditions of Different Reactor Designs for Methane Cracking.

\section{Conclusions and outlook}

The research to find an alternative fuel to fossil fuels is led by how the new technologies are economically competitive with the fossil fuel technologies, rather than their efficiencies. However, the economical aspect of fossil fuels should also include the cost for $\mathrm{CO}_{2}$ emissions or sequestration of $\mathrm{CO}_{2}$ when fossil fuels are compared to solar fuels since solar fuels have no $\mathrm{CO}_{2}$ emission. Furthermore, as the fossil fuels deplete and the demand for fossil fuels will exceed their production, their prices will be subjected to significant increase. In this way, the investors in fuel or electricity production sector would see solar fuels as an alternative to fossil fuels with the current level of both technologies. As an outcome, the world 
would become a more sustainable environment with reduced atmospheric $\mathrm{CO}_{2}$ level and less pronounced risk for global warming.

It should also be noted that the solar fuel production methods introduced in this chapter are at different levels of maturity. For instance, most of the thermochemical cycles are in laboratory and research scale, whereas gasification and reforming processes are in fully operational or pilot stage. To give some examples on solar fuel production, the targets and predictions of the US Department of Energy (DOE) [78] for both cost and process efficiency are summarized in Table 4 for the $\mathrm{ZnO} / \mathrm{Zn}$ thermochemical cycle. The predictions show that it is possible and feasible to meet the DOE efficiency and 2015 cost targets. However, the cost target of DOE in 2025 is a challenging objective. The main constituent of cost in thermochemical solar production is the plant capital cost, i.e., cost for heliostats and solar tower, rather than the direct cost for the process. Although process efficiencies are reported and predicted as given in Table 4, the overall solar-to-fuel conversions are still low, less than $10 \%$ [1].

\begin{tabular}{ccccc}
\hline & by 2015 & \multicolumn{2}{c}{ by $\mathbf{2 0 2 5}$} \\
\hline & DOE Target & Prediction $^{\ddagger}$ & DOE Target & Prediction $^{\ddagger}$ \\
\hline Cost $\left(\$ / g^{\dagger}\right)^{\dagger}$ & 6 & 6.07 & 3 & 4.18 \\
\hline Process Efficiency $(\%)$ & 30 & 35 & 35 & 42 \\
\hline
\end{tabular}

${ }^{\dagger}$ gge refers to gallon-of-gas-equivalent.

‡Based on predicted ZnO-to-Zn conversions of $70 \%$ in 2015 and $85 \%$ in 2025.

Table 4. Targets of Department of Energy of US [14] and predictions [78] for cost and efficiency for $\mathrm{ZnO} / \mathrm{Zn}$ thermochemical cycle.

In summary, the advantages of solar fuels include:

- Energy content or heating value of feedstock is increased by converting it to another form, solar fuel.

- Producing storable and transportable fuel which is not possible if solar energy is directly used. Thus, eliminates the intermittency problem of solar energy.

- Solar fuels are clean and sustainable. The thermochemical cycles and thermolysis of water that are used to produce solar fuels have no $\mathrm{CO}$ or $\mathrm{CO}_{2}$ emissions. However, carbon emission occurs for the gasification or reforming of carbonecous feedstocks. If these feedstocks are biomass cultivated with $\mathrm{CO}_{2}$ from the atmosphere, they are carbon neutral.

On the other hand, these are not mature technologies and still suffer from technical challenges which form the basis for future research including:

- High temperatures needed for solar fuel production processes. High temperatures can be reached with high concentrating ratios. However, high concentrating ratios bring high cost to the system, and high temperatures restrict the material choice. 
- Recombination of product gases, especially in thermochemical cycles, is a significant problem. This recombination significantly decreases both the process and overall solar-tofuel efficiency.

- Quenching is introduced to products in order to reduce the recombination. However, quenching adds additional cost and complexity to the reactor and the process management. For some solar thermochemical processes, membranes are also required to separate product gases.

- Particle accumulation on the window of the reactor is a problem in directly irradiated solar reactors. This problem can be eliminated by introducing an inert gas with high flow rates to the reactor which further complicates the management of reaction in the reactor. Another solution is to heat the reactor indirectly which reduces the solar-to-fuel efficiency.

- Multiple-step chemical reactions are needed to produce hydrogen in most of the thermochemical cycles. More reactions add further components to the system which increase the cost and the management of the overall fuel production process.

- $\mathrm{CO}$ and $\mathrm{CO}_{2}$ formation can be noteworthy in case of solar gasification and reforming of carbonecous feedstock, although solar fuels are accepted as clean fuels.

These drawbacks of the solar fuel production prevent the technology to be converted to large scale commercially available power plants. However, solar fuel production processes are thermodynamically efficient, favorable developments to increase the feedstock's heating values with the unlimited free solar energy. Therefore, in a long-term prospect, solar fuel production is a promising technology that needs significant research efforts for efficiently producing clean and sustainable fuels.

\section{Author details}

Onur Taylan and Halil Berberoglu*

Department of Mechanical Engineering, The University of Texas at Austin, Austin, TX, USA

\section{References}

[1] Nowotny J, Sorrell C, Sheppard L, Bak T. Solar-Hydrogen: Environmentally Safe Fuel for the Future. International Journal of Hydrogen Energy. 2005;30(5):521-44.

[2] Steinfeld A, Palumbo R. Solar Thermochemical Process Technology. Encyclopedia of Physical Science and Technology. 2001;15(1):237-56.

[3] Steinfeld A, Meier A. Solar Fuels and Materials. Amsterdam: Elsevier; 2004. p. 62337. 
[4] Baykara S. Experimental Solar Water Thermolysis. International Journal of Hydrogen Energy. 2004;29(14):1459-69.

[5] Steinfeld A. Solar Hydrogen Production via a Two-Step Water-Splitting Thermochemical Cycle Based on $\mathrm{Zn} / \mathrm{ZnO}$ Redox Reactions. International Journal of Hydrogen Energy. 2002;27(6):611-9.

[6] Funke HH, Diaz H, Liang X, Carney CS, Weimer AW, Li P. Hydrogen Generation by Hydrolysis of Zinc Powder Aerosol. International Journal of Hydrogen Energy. 2008;33(4):1127-34.

[7] Abanades S, Charvin P, Lemont F, Flamant G. Novel Two-Step $\mathrm{SnO}_{2} / \mathrm{SnO}$ WaterSplitting Cycle for Solar Thermochemical Production of Hydrogen. International Journal of Hydrogen Energy. 2008;33(21):6021-30.

[8] Meier A, Steinfeld A. Solar Thermochemical Production of Fuels. Advances in Science and Technology. 2011;74(1):303-12.

[9] Chueh WC, Haile SM. Ceria as a Thermochemical Reaction Medium for Selectively Generating Syngas or Methane from $\mathrm{H}_{2} \mathrm{O}$ and $\mathrm{CO}_{2}$. ChemSusChem. 2009;2(8):735-9.

[10] Kappauf T, Fletcher EA. Hydrogen and Sulfur from Hydrogen Sulfide-VI. Solar Thermolysis. Energy. 1989;14(8):443-9.

[11] Zaman J, Chakma A. Production of Hydrogen and Sulfur from Hydrogen Sulfide. Fuel processing technology. 1995;41(2):159-98.

[12] Steinfeld A. Solar Thermochemical Production of Hydrogen - a Review. Solar energy. 2005;78(5):603-15.

[13] Harvey WS, Davidson JH, Fletcher EA. Thermolysis of Hydrogen Sulfide in the Temperature Range 1350-1600 K. Industrial \& engineering chemistry research. 1998;37(6): 2323-32.

[14] Perret R. Solar Thermochemical Hydrogen Production Research (STCH), Thermochemical Cycle Selection and Investment Priority. Albuquerque, New Mexico and Livermore, California: Sandia National Laboratories 2011. Report No.: SAND20113622.

[15] Perkins C, Weimer AW. Solar-Thermal Production of Renewable Hydrogen. AIChE Journal. 2009;55(2):286-93.

[16] Zedtwitz P, Steinfeld A. The Solar Thermal Gasification of Coal-Energy Conversion Efficiency and $\mathrm{CO}_{2}$ Mitigation Potential. Energy. 2003;28(5):441-56.

[17] Maag G, Zanganeh G, Steinfeld A. Solar Thermal Cracking of Methane in a ParticleFlow Reactor for the Co-Production of Hydrogen and Carbon. International Journal of Hydrogen Energy. 2009;34(18):7676-85.

[18] Hirsch D, Epstein M, Steinfeld A. The Solar Thermal Decarbonization of Natural Gas. International Journal of Hydrogen Energy. 2001;26(10):1023-33. 
[19] Ozalp N, Kogan A, Epstein M. Solar Decomposition of Fossil Fuels as an Option for Sustainability. International Journal of Hydrogen Energy. 2009;34(2):710-20.

[20] Rodat S, Abanades S, Coulié J, Flamant G. Kinetic Modelling of Methane Decomposition in a Tubular Solar Reactor. Chemical Engineering Journal. 2009;146(1):120-7.

[21] Abanades S, Flamant G. Hydrogen Production from Solar Thermal Dissociation of Methane in a High-Temperature Fluid-Wall Chemical Reactor. Chemical Engineering and Processing: Process Intensification. 2008;47(3):490-8.

[22] Almodaris M, Khorasani S, Abraham JJ, Ozalp N, editors. Simulation of Solar Thermo-Chemical Hydrogen Production Techniques. ASME/JSME 2011 8th Thermal Engineering Joint Conference; 2011 March 13-17, 2011; Honolulu, Hawaii, USA: ASME.

[23] Rodat S, Abanades S, Flamant G. High-Temperature Solar Methane Dissociation in a Multitubular Cavity-Type Reactor in the Temperature Range 1823 - 2073 K. Energy \& fuels. 2009;23(5):2666-74.

[24] Kamka F, Jochmann A, Picard L, editors. Development Status of BGL Gasification. International Freiberg Conference on IGCC \& XtL Technologies; 2005; Freiberg, Germany.

[25] Higman C, Burgt Mvd. Gasification. Second ed. Oxford, UK: Gulf Professional Publishing; 2008.

[26] Basu P. Biomass Gasification and Pyrolysis: Practical Design and Theory. Burlington, MA: Academic Press; 2010.

[27] Kodama T, Kondoh Y, Tamagawa T, Funatoh A, Shimizu K, Kitayama Y. Fluidized Bed Coal Gasification with $\mathrm{CO}_{2}$ under Direct Irradiation with Concentrated Visible Light. Energy \& fuels. 2002;16(5):1264-70.

[28] Aoki A, Ohtake H, Shimizu T, Kitayama Y, Kodama T. Reactive Metal-Oxide Redox System for a Two-Step Thermochemical Conversion of Coal and Water to CO and $\mathrm{H}_{2}$. Energy. 2000;25(3):201-18.

[29] Flechsenhar M, Sasse C. Solar Gasification of Biomass Using Oil Shale and Coal as Candidate Materials. Energy. 1995;20(8):803-10.

[30] Van Heek K. General Aspects and Engineering Principles for Technical Application of Coal Gasification. In: Figuieiredo JL, Moulijn JA, editors. Carbon and Coal Gasification: Science and Technology. Alvor, Portugal: Springer; 1986. p. 383-402.

[31] Piatkowski N, Wieckert C, Steinfeld A. Experimental Investigation of a Packed-Bed Solar Reactor for the Steam-Gasification of Carbonaceous Feedstocks. Fuel processing technology. 2009;90(3):360-6.

[32] Devi L, Ptasinski KJ, Janssen FJJG. A Review of the Primary Measures for Tar Elimination in Biomass Gasification Processes. Biomass and Bioenergy. 2003;24(2):125-40. 
[33] Weimer A, Perkins C, Mejic D, Lichty P, inventors; WO Patent WO/2008/027,980, assignee. Rapid Solar-Thermal Conversion of Biomass to Syngas. United States patent WO2008027980. 2008 06.03.2008.

[34] Quaschning V. Technology Fundamentals. Solar Thermal Power Plants. Renew Energy World. 2003;6(6):109-13.

[35] Fernández-García A, Zarza E, Valenzuela L, Pérez M. Parabolic-Trough Solar Collectors and Their Applications. Renewable and Sustainable Energy Reviews. 2010;14(7): 1695-721.

[36] Morrison G, Budihardjo I, Behnia M. Water-in-Glass Evacuated Tube Solar Water Heaters. Solar energy. 2004;76(1):135-40.

[37] Duffie JA, Beckman WA. Solar Engineering of Thermal Processes. 3rd ed. New Jersey: John Wiley \& Sons; 2006.

[38] Mills DR, Morrison GL. Compact Linear Fresnel Reflector Solar Thermal Powerplants. Solar energy. 2000;68(3):263-83.

[39] Acciona North America. Nevada Solar One. http://www.acciona-na.com/About-Us/ Our-Projects/U-S-/Nevada-Solar-One (accessed September 9, 2012).

[40] California Energy Commission. Large Solar Energy Projects. http://www.energy.ca.gov/siting/solar/ (accessed September 9, 2012).

[41] Wald ML. The New York Times: In the Desert, Harnessing the Power of the Sun by Capturing Heat Instead of Light. http://www.nytimes.com/2007/07/17/business/ 17thermal.html?_r=1 (accessed September 18, 2012).

[42] Areva. Our Technology and Features. http://www.areva.com/EN/solar-198/arevasolarour-technology.html\#tab=tab2 (accessed September 9, 2012).

[43] Abbas R, Montes M, Piera M, Martínez-Val J. Solar Radiation Concentration Features in Linear Fresnel Reflector Arrays. Energy Conversion and Management. 2012;54(1): 133-44.

[44] National Renewable Energy Laboratory. Puerto Errado 2 Thermosolar Power Plant. http://www.nrel.gov/csp/solarpaces/project_detail.cfm/projectID=159 (accessed September 9, 2012).

[45] Novatec Solar. Puerto Errado 2 in Spain. http://www.novatecsolar.com/56-1PE-2.html (accessed September 9, 2012).

[46] Tubosol PE2. Puerto Errado 2 (in German). http://www.puertoerrado2.com/ (accessed September 18, 2012).

[47] Ummadisingu A, Soni M. Concentrating Solar Power-Technology, Potential and Policy in India. Renewable and Sustainable Energy Reviews. 2011;15(9):5169-75.

[48] Kaygusuz K. Prospect of Concentrating Solar Power in Turkey: The Sustainable Future. Renewable and Sustainable Energy Reviews. 2011;15(1):808-14. 
[49] SRP. Tessera Solar and Stirling Energy Systems Unveil World's First CommercialScale Suncatcher Plant, Maricopa Solar - Peoria, Arizona. http://energydeals.wordpress.com/2010/06/04/tessera-solar-and-stirling-energy-systems-unveil-worlds-firstcommercial-scale-suncatcher-plant-maricopa-solar-with-partner-srp/ (accessed September 18, 2012).

[50] United States Environmental Protection Agency. Final Report: Design and Fabrication of a Reduced Cost Heliostat. http://cfpub.epa.gov/ncer_abstracts/index.cfm/ fuseaction/display.abstractDetail/abstract/9033/report/F (accessed September 10, 2012).

[51] Pitz-Paal R, Botero NB, Steinfeld A. Heliostat Field Layout Optimization for HighTemperature Solar Thermochemical Processing. Solar energy. 2011;85(2):334-43.

[52] Jones SA, Lumia R, Davenport R, Thomas RC, Gorman D, Kolb GJ, et al. Heliostat Cost Reduction Study. Albuquerque, New Mexico and Livermore, California.: Sandia National Laboratories 2007. Report No.: SAND2007-3293.

[53] National Renewable Energy Laboratory. Planta Solar 20. http://www.nrel.gov/csp/ solarpaces/project_detail.cfm/projectID=39 (accessed September 10, 2012).

[54] Solar Reserve. Crescent Dunes. http://www.solarreserve.com/what-we-do/cspprojects/crescent-dunes/ (accessed September 10, 2012).

[55] Abengoa Solar. PS20, the Largest Solar Power Tower Worldwide. http://www.abengoasolar.com/corp/web/en/nuestras_plantas/plantas_en_operacion/espana/ PS20_la_mayor_torre_comercial_del_mundo.html (accessed September 18, 2012).

[56] Ávila-Marín AL. Volumetric Receivers in Solar Thermal Power Plants with Central Receiver System Technology: A Review. Solar energy. 2011;85(5):891-910.

[57] Pavlović TM, Radonjić IS, Milosavljević DD, Pantić LS. A Review of Concentrating Solar Power Plants in the World and Their Potential Use in Serbia. Renewable and Sustainable Energy Reviews. 2012;16(6):3891-902.

[58] Yeheskel J, Epstein M. Thermolysis of Methane in a Solar Reactor for Mass-Production of Hydrogen and Carbon Nano-Materials. Carbon. 2011;49(14):4695-703.

[59] Abanades S, Flamant G. Experimental Study and Modeling of a High-Temperature Solar Chemical Reactor for Hydrogen Production from Methane Cracking. International Journal of Hydrogen Energy. 2007;32(10-11):1508-15.

[60] Abanades S, Flamant G. Production of Hydrogen by Thermal Methane Splitting in a Nozzle-Type Laboratory-Scale Solar Reactor. International Journal of Hydrogen Energy. 2005;30(8):843-53.

[61] Klein HH, Karni J, Rubin R. Dry Methane Reforming without a Metal Catalyst in a Directly Irradiated Solar Particle Reactor. Journal of solar energy engineering. 2009;131(2):021001. 
[62] Z'graggen A, Haueter P, Trommer D, Romero M, De Jesus J, Steinfeld A. Hydrogen Production by Steam-Gasification of Petroleum Coke Using Concentrated Solar Power-II Reactor Design, Testing, and Modeling. International Journal of Hydrogen Energy. 2006;31(6):797-811.

[63] Gordillo E, Belghit A. A Bubbling Fluidized Bed Solar Reactor Model of Biomass Char High Temperature Steam-Only Gasification. Fuel processing technology. 2010;92(3):314-21.

[64] Gordillo E, Belghit A. A Downdraft High Temperature Steam-Only Solar Gasifier of Biomass Char: A Modelling Study. Biomass and Bioenergy. 2011;35(5):2034-43.

[65] Hathaway BJ, Davidson JH, Kittelson DB. Solar Gasification of Biomass: Kinetics of Pyrolysis and Steam Gasification in Molten Salt. Journal of solar energy engineering. 2011;133(2):021011.

[66] Rodat S, Abanades S, Flamant G. Co-Production of Hydrogen and Carbon Black from Solar Thermal Methane Splitting in a Tubular Reactor Prototype. Solar energy. 2011;85(4):645-52.

[67] Rodat S, Abanades S, Sans JL, Flamant G. Hydrogen Production from Solar Thermal Dissociation of Natural Gas: Development of a $10 \mathrm{~kW}$ Solar Chemical Reactor Prototype. Solar energy. 2009;83(9):1599-610.

[68] Rodat S, Abanades S, Flamant G, editors. Hydrogen Production from Natural Gas Thermal Cracking: Design and Test of a Pilot-Scale Solar Chemical Reactor. 18th World Hydrogen Energy Conference 2010; 2010 May 16-21, 2010; Essen, Germany.

[69] Lichty P, Perkins C, Woodruff B, Bingham C, Weimer A. Rapid High Temperature Solar Thermal Biomass Gasification in a Prototype Cavity Reactor. Journal of solar energy engineering. 2010;132(1):011012.

[70] Wullenkord M, Funken KH, Sattler C, Pitz-Paal R, Stolten D, Grube T, editors. Hydrogen Production by Thermal Cracking of Methane-Investigation of Reaction Conditions. 18th World Hydrogen Energy Conference; 2010; Essen, Germany.

[71] Worner A, Tamme R. CO2 Reforming of Methane in a Solar Driven Volumetric Receiver-Reactor. Catalysis today. 1998;46(2-3):165-74.

[72] Maag G, Rodat S, Flamant G, Steinfeld A. Heat Transfer Model and Scale-up of an Entrained-Flow Solar Reactor for the Thermal Decomposition of Methane. International Journal of Hydrogen Energy. 2010;35(24):13232-41.

[73] Osinga T, Olalde G, Steinfeld A. Solar Carbothermal Reduction of ZnO: Shrinking Packed-Bed Reactor Modeling and Experimental Validation. Industrial \& engineering chemistry research. 2004;43(25):7981-8.

[74] Osinga T, Frommherz U, Steinfeld A, Wieckert C. Experimental Investigation of the Solar Carbothermic Reduction of ZnO Using a Two-Cavity Solar Reactor. Journal of solar energy engineering. 2004;126(1):633-7. 
[75] Epstein M, Olalde G, Santén S, Steinfeld A, Wieckert C. Towards the Industrial Solar Carbothermal Production of Zinc. Journal of Solar Energy Engineering. 2008;130(1): 014505.

[76] Wieckert C, Frommherz U, Kräupl S, Guillot E, Olalde G, Epstein M, et al. A 300 Kw Solar Chemical Pilot Plant for the Carbothermic Production of Zinc. Journal of Solar Energy Engineering. 2007;129(2):190-6.

[77] Piatkowski N, Steinfeld A. Solar-Driven Coal Gasification in a Thermally Irradiated Packed-Bed Reactor. Energy \& Fuels. 2008;22(3):2043-52.

[78] Kromer M, Roth K, Takata R, Chin P. Support for Cost Analyses on Solar-Driven High Temperature Thermochemical Water-Splitting Cycles. Lexington, MA: TIAX, LLC2011 February 22, 2011. Report No.: DE-DT0000951. 
